\author{
UNIVERSIDADE DE SÃO PAULO \\ INSTITUTO DE PSICOLOGIA \\ DEPARTAMENTO DE PSICOLOGIA CLÍNICA
}

LÍVIA MARIA RAMOS BATISTA

Psicoterapia Breve Operacionalizada em gestantes diabéticas 1 com mau controle glicêmico

SÃO PAULO

2015 


\section{Psicoterapia Breve Operacionalizada em gestantes diabéticas 1 com mau controle glicêmico}

(Versão corrigida)

Dissertação de Mestrado apresentado ao Programa de Pós-Graduação em Psicologia Clínica do Instituto de Psicologia da Universidade de São Paulo.

Área de concentração: Psicologia Clínica Orientadora: Prof. ${ }^{a}$ Kayoko Yamamoto 
AUTORIZO A REPRODUÇÃO E DIVULGAÇÃO TOTAL OU PARCIAL DESTE TRABALHO, POR QUALQUER MEIO CONVENCIONAL OU ELETRÔNICO, PARA FINS DE ESTUDO E PESQUISA, DESDE QUE CITADA A FONTE.

Catalogação na publicação

Biblioteca Dante Moreira Leite

Instituto de Psicologia da Universidade de São Paulo

Batista, Lívia Maria Ramos.

Psicoterapia breve operacionalizada em gestantes diabéticas 1 com mau controle glicêmico / Lívia Maria Ramos Batista; orientadora Kayoko Yamamoto. -- São Paulo, 2015.

$84 \mathrm{f}$.

Dissertação (Mestrado - Programa de Pós-Graduação em Psicologia. Área de Concentração: Psicologia Clínica) - Instituto de Psicologia da Universidade de São Paulo.

1. Psicoterapia Breve Operacionalizada 2. Escala Diagnóstica Adaptativa Operacionalizada 3. Gravidez 4. Diabetes Mellitus insulino-dependente 5. Mau controle glicêmico I. Título.

RC489.B8 
Nome: Batista, Lívia Maria Ramos

Título: Psicoterapia Breve Operacionalizada em gestantes diabéticas 1 com mau controle glicêmico

Dissertação apresentada ao Instituto de Psicologia da Universidade de São Paulo para obtenção do título de Mestre em Psicologia

Aprovada em:

Banca Examinadora

Prof. Dr.

Instituição:

Assinatura

Prof. Dr.

Instituição:

Assinatura

Prof. Dr.

Instituição: Assinatura 
Ao Marcelo, por seu carinho e dedicação, Aos queridos filhos Luã, Luc e Leo pelo amor que me motiva todos os dias, Aos meus pais pela inspiração a apoio infinitos... 


\section{AGRADECIMENTOS}

Agradeço:

à Dra. Kayoko Yamamoto, por seus ensinamentos tão necessários à minha jornada científica e por sua imensa paciência e cooperação;

ao Dr. Ryad Simon, por compartilhar os pilares fundamentais à realização desta obra;

à Dra Sueli Rossini, que com sua dedicação e conhecimento clarificou com sabedoria às névoas da psicologia humana;

à Dra. Rossana Pulcineli Vieira Francisco e ao Dr. Marcelo Zugaib que abriram as portas da Clínica Obstétrica do Hospital das Clínicas da Faculdade de Medicina da Universidade de São Paulo, compartilhando seus pacientes e permitindo a realização desta pesquisa;

à enfermeira Dra. Ana Maria por seu acolhimento e boa vontade;

aos médicos Dr. Rodrigo Rocha Codarin e Dra. Rafaela Alkmin da Costa pelos encaminhamentos e esclarecimentos fundamentais à realização deste trabalho;

aos funcionários da biblioteca por prontamente e atenciosamente me auxiliarem em todas minhas dúvidas; 
Batista, L. M. R. (2015). Psicoterapia Breve Operacionalizada em gestantes diabéticas 1 com mau controle glicêmico. Dissertação de Mestrado, Departamento de Psicologia Clínica do Instituto de Psicologia da Universidade de São Paulo, São Paulo.

\section{RESUMO}

O Ministério da Saúde adverte que o Diabetes Mellitus é um problema de saúde pública devido sua alta taxa de prevalência. Estudos demonstram a correlação entre o funcionamento psicodinâmico de pacientes com diabetes mellitus tipo 1 e o controle glicêmico. Considerando que o controle glicêmico adequado minimiza os riscos para a mãe, o feto e o futuro bebê, salienta-se a importância de um atendimento psicoterápico na fase gestacional. Contudo, não existem pesquisas sobre Psicoterapia Breve Operacionalizada (PBO) enquanto técnica terapêutica para este tipo de população. O objetivo da pesquisa foi investigar possibilidades e limites da PBO no atendimento a gestantes portadoras de diabetes mellitus tipo 1 (DM1) com mau controle glicêmico. A metodologia utilizada para a pesquisa foi o clinico-qualitativo. $\mathrm{O}$ estudo envolveu quatro gestantes portadoras de DM1 com mau controle glicêmico. As gestantes foram encaminhadas pela Clínica Obstétrica do Hospital das Clínicas da Faculdade de Medicina da Universidade de São Paulo, local onde as mesmas são atendidas. Foram utilizados como instrumentos: entrevista clínica psicológica; Escala Diagnóstica Adaptativa Operacionalizada; e Psicoterapia Breve Operacionalizada. As gestantes que concordaram em participar assinaram o Termo de Consentimento Livre e Esclarecido que após lido e explicado, foi assinado pela pesquisadora e gestante. Foram realizadas duas ou três entrevistas inicias para o diagnóstico adaptativo operacionalizado e planejamento da PBO. O número de sessões utilizadas para PBO foi definido conforme o diagnóstico adaptativo da gestante e sua situação-problema. As entrevistas e as sessões psicoterápicas tiveram duração de 45 minutos e frequência de uma vez por semana. A análise dos resultados foi realizada através da comparação entre o diagnóstico adaptativo operacionalizado realizado antes e depois da PBO. Foi verificado se ocorreu nas gestantes, durante estes períodos, mudanças adaptativas; além da averiguação das alterações no controle glicêmico, antes e após a PBO. A pesquisa expôs que houve mudanças de grupo adaptativo da qual as gestantes pertenciam. Cecília e Beatriz obtiveram melhora no diagnóstico adaptativo. Por intermédio do acompanhamento da evolução do controle glicêmico, pode-se verificar alterações com o decorrer da PBO: a porcentagem de hipoglicemias e hipoglicemias graves melhoraram; as porcentagens de valores alterados e de hiperglicemias, por sua vez, tiveram piora com o decorrer da gravidez, e, mesmo com a PBO, o rigoroso controle alimentar e insulinoterapia, inclusive em internações, foram dificilmente controlados. Das quatro gestantes estudadas duas tiveram crise adaptativa e as soluções encontradas por elas foram satisfatórias. O que pode restringir o processo psicoterapêutico é a transferência negativa persistente, contudo, ela pode ser trabalhada e minimizada. As possibilidades da PBO no atendimento às gestantes com DM1 encontradas na pesquisa foram: melhorar a eficácia da adaptação; auxiliar as pacientes em crise a solucionarem-na sem a queda da eficácia da adaptação; e, possibilitar as pacientes encontrarem soluções mais adequadas para suas situações-problema.

Palavra-chave: Psicoterapia Breve Operacionalizada, Escala Diagnóstica Adaptativa Operacionalizada, Gravidez, Diabetes Mellitus insulino-dependente e mau controle glicêmico. 
Batista, L. M. R. (2015). Operationalized Brief Psychotherapy in diabetic 1 pregnant women with deficient glycemic control. Dissertation, Department of Clinical Psychology at the Institute of Psychology, São Paulo University, São Paulo.

\begin{abstract}
The health ministry adverts that Diabetes Mellitus is a public health concern due to its high prevalence rate. Studies demonstrate the existing relation between the psychodynamic functioning of patients with type 1 diabetes mellitus and the glycemic control. Considering that the adequate glycemic control minimizes risks for the mother, fetus and the future baby, it reinforces the importance of psychotherapeutic treatment during the pregnancy. However, there aren't any researches on Operationalized Brief Psychotherapy (OBP) as a therapeutic technique for this kind of population. The aim of the research was to investigate the possibilities and the limits of OBP in the treating of pregnant women with type 1 diabetes mellitus with deficient glycemic control. The methodology used for the research was the clinical-qualitative method. The study involved four pregnant women with DM1 with deficient glycemic control. The women were appointed by the Obstetric Clinic of the Hospital das Clínicas da Faculdade de Medicina from the University of São Paulo, place where they were already being treated. The instruments employed were Psychological Interviews, the Operationalized Adaptive Diagnosis Scale and Operationalized Brief Psychotherapy. The women who agreed to take part in the research signed a consent form that, after read and explained, was then signed by the research agent and the subjects. Two or three initial interviews took place for the Operationalized Adaptive Diagnosis and the planning of the. The number of sessions employed for the OPB was defined in accordance to the adaptive diagnosis of the subject and their problem-situation. The interviews and the psychotherapeutic sessions lasted 45 minutes with the frequency of once a week. The analysis of the results was made through the comparison between the operationalized adaptive diagnosis done before and after the OPB. During these periods, it was verified if there were any adaptive changes in the subjects and, moreover, the analysis of any alterations in the glycemic control before and after the OPB. The research showed that there were changes in the adaptive group to which the subjects belonged. Cecília and Beatriz had an improvement in the adaptive diagnosis. Through the analysis of the evolution of the glycemic control, it was possible to verify alterations during the OPB: the percentage of both hypoglycemia and severe hypoglycemia showed improvement; however, the percentage of altered rates and of hyperglycemia showed a downturn throughout the pregnancy and, even with the OPB, a strict diet control and insulin therapy, including during admissions, were hardly controlled. From the four pregnant women in the study, two of them had an adaptive crisis and the solution found by them was satisfactory. What can restrict the therapeutic process is the persisting negative transference, however, it can be minimized. The possibilities of the OPB in the treatment of pregnant women with DM1 found with the research were: improving the efficiency of the adaptation, assisting patients in crisis to resolve them without losses in adaptation efficiency and, make patients more able to find more adequate solutions to their problem-situations.
\end{abstract}

Key words: Operationalized Brief Psychotherapy, Operationalized Adaptive Diagnosis Scale, Pregnancy, Diabetes Mellitus insulin dependant and deficient glycemic control. 


\section{LISTA DE TABELAS}

Tabela 1 - Diagnóstico adaptativo no decorrer do processo psicoterápico.......................................................47

Tabela 2 - Análise dos setores da EDAO antes, depois da PBO e no follow up............................................................48

Tabela 3 - \% de medidas de glicemia alteradas nas fases de atendimento...........................................................48 


\section{LISTA DE FIGURAS}

Figura 1 - Matriz gráfica do caso Ana........................................................................33

Figura 2 - Matriz gráfica do caso Beatriz..................................................................36

Figura 3 - Matriz gráfica do caso Cecília...................................................................43

Figura 4 - Matriz gráfica do caso Denise............................................................................46 


\section{LISTA DE GRÁFICOS}

Gráfico 1 - Média do controle glicêmico nas

diversas fases de atendimento (Caso Ana)..........................................33

Gráfico 2 - Média do controle glicêmico nas

diversas fases de atendimento (Caso Beatriz)...........................................41 


\section{LISTA DE QUADROS}

Quadro 1 - Características gerais das

participantes da pesquisa.

Quadro 2 - Características do DM1 e do

controle glicêmico nas fases da vida....................................................28

Quadro 3 - Características gerais da

vida reprodutiva das participantes. 


\section{LISTA DE ABREVIATURAS E SIGLAS}

A
A-R
C
DM Diabetes Mellitus

DMG Diabetes Mellitus gestacional

DM1 Diabetes Mellitus tipo 1

DM2 Diabetes Mellitus tipo 2

EDAO Escala Diagnóstica Adaptativa Operacionalizada

$\mathrm{f} / \mathrm{d} \quad$ Fator defensivo

f/e $\quad$ Fator externo

f/i $\quad$ Fator interno

f/Oe $\quad$ Fator Objetal externo

f/Oi Fator Objetal interno

$\mathrm{f} / \mathrm{t} \quad$ Fator tensional

G1 Grupo um

G2 Grupo dois

G3 Grupo três

G4 Grupo quatro

G5 Grupo cinco

HCFMUSP Hospital das Clínicas da Faculdade de Medicina da Universidade de São Paulo

Or Orgânico

P Pouco adequado

PBO Psicoterapia Breve Operacionalizada

Pq Pouquíssimo adequado

Pr Produtividade

SIBI Sistema integrado de bibliotecas Universidade de São Paulo 
SISDAO Sistema Diagnóstico Adaptativo Operacionalizado

SUS Sistema Único de Saúde

S-C Sociocultural

S/p Situação-problema

TAT Teste de Apercepção Temática 


\section{SUMÁRIO}

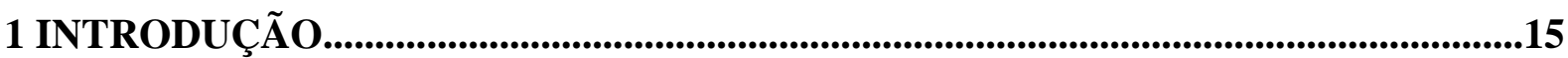

$\begin{array}{llll}1.1 & \text { A transição } & \text { existencial }\end{array}$

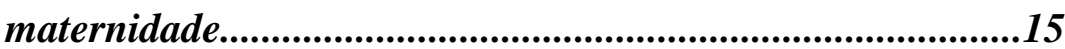

$\begin{array}{llll}\text { Gravidez } & \text { de } & \text { alto }\end{array}$

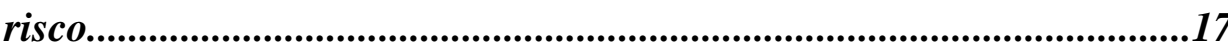

1.3 Diabetes mellitus na

gestação.........................................................................................................18

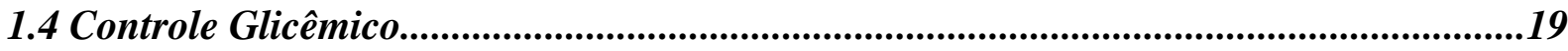

1.5 Psicodinamismo de gestantes de

DM1 .20

$\begin{array}{llll}\text { 1.6 Sistema Diagnóstico } & \text { Adaptativo }\end{array}$

Operacionalizado. .23

1.7 Escala Diagnóstica Adaptativa

Operacionalizada. .23

1.8 Crise $\quad$ Adaptativa $\quad-\quad$ sua $\quad$ prevenção $\quad e$ prognóstico.................................................................25

1.9 Entrevistas Clínicas

Psicológicas...............................................................................26

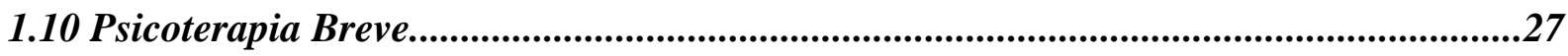

1.11 Psicoterapia Breve Operacionalizada........................................................................................28

1.12 Campo de pesquisas em $\mathrm{EDAO}$

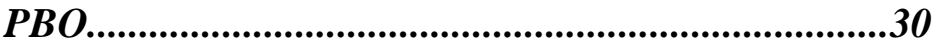

1.13

Justificativa.

1.14

Objetivos.

1.14.1

Objetivo

geral

. .32

1.14.2

Objetivos

específicos. .32 
2.2

Material. .34

2.2.1 Participantes. . .34

2.2.1.2 Critérios inclusão .34

2.2.2 Local. .35

2.2.3 Instrumentos. . .35

2.2.4 Procedimento. .35

2.2.5

Análise

dos aspectos

éticos. .36

3 RESULTADOS dos . .38

3.1 Apresentação . .39

clínicos.

Caso

3.1.1 . .39

Ana.

3.1.2 Caso Beatriz. .044

3.1.3 Caso

Cecília. .52

3.1.4 Caso Denise......................................................................................................................................55

4 DISCUSSÃ

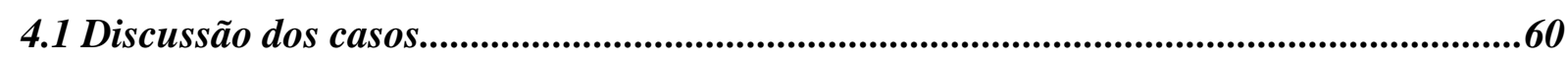

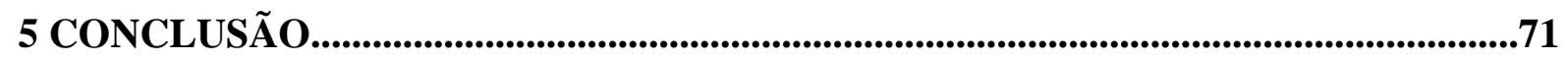

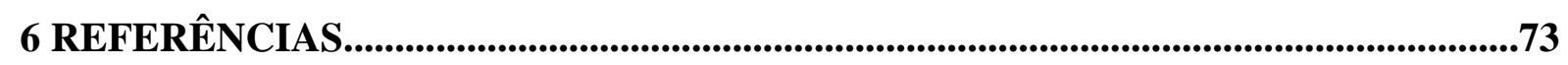

ANEXO

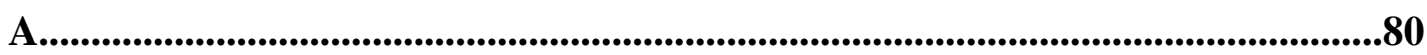

ANEXO B

ANEXO

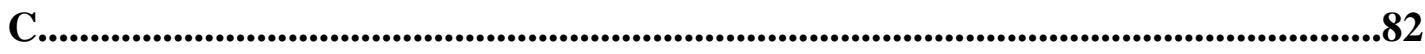





\section{INTRODUÇÃO}

No grupo de pesquisa coordenado pela Prof. ${ }^{a}$. Dr ${ }^{\mathrm{a}}$. Kayoko Yamamoto intitulado “Estudo Piloto da Validade de Predição da Escala Pós-parto de Edimburgo” algumas gestantes diabéticas participaram do estudo e foi percebido o quanto esta patologia mexe emocionalmente com a gestante pois o bom controle glicêmico é dificilmente alcançado e, ele minimiza, em muito, os riscos para o feto e para a mãe. Surgiu então, o interesse em aprofundar conhecimentos sobre gestantes portadoras de DM tipo 1 e os atendimentos psicológicos utilizados para esta população. Ao realizar busca por literatura acadêmica foi constatado a pouca quantidade de pesquisas relacionadas ao atendimento psicoterápico em gestantes com DM1 e mau controle glicêmico. Os profissionais de saúde da Clínica Obstétrica do Hospital das Clínicas da Faculdade de Medicina da Universidade de São Paulo (HCFMUSP) confirmaram a necessidade de pesquisas na área e a importância de estudos sobre tratamentos psicológicos que possam melhorar o controle glicêmico de gestantes com DM1.

Foi relatado pelos médicos que as gestantes com DM1 apresentam dificuldades em adotarem mudanças no tratamento do diabetes - mudanças essas exigidas pela gravidez. Foi relatado ainda que existe nestas gestantes a fantasia de que a variação glicêmica era causada pelo feto que estaria "roubando" sua glicose. E, também, a presença de intensa ambivalência em relação a gravidez, como, por exemplo, abortar ou prosseguir com ela, o que levaria a interferir em sua vinculação ao feto.

Para contextualizar e justificar este estudo foram englobados na Introdução os aspectos psicológicos da gravidez, a gravidez de alto risco, o diabetes mellitus na gestação, o psicodinamismo de gestantes diabéticas, psicoterapia breve, além da técnica e pesquisas atuais sobre PBO.

\subsection{A transição existencial na maternidade}

Segundo Maldonado (2002), a maternidade é um momento no qual novas adaptações são imprescindíveis, devido às transformações no papel social e redefinições interpessoais e intrapsíquicas. A gravidez requer a reorganização e regulação de diversos aspectos. Além de filha e mulher, a gestante passará a ser mãe. Dessa forma, a mudança de identidade pode trazer à tona antigos conflitos de relacionamento.

A gestação é um fenômeno complexo, dinâmico e transformador. Vai além das transformações físicas, englobando aspectos socioculturais. O processo pela busca da identidade materna inicia-se com a descoberta da gravidez, passando pela experiência do 
efeito desta em seu meio social e sua aceitação. Estas etapas levam a primeira decisão da gestante: manter ou interromper a gestação. A partir desta decisão a gestante passa a se reconhecer como tal, vivenciando as transformações corporais e as repercussões em seu meio social (Camacho, Vargens, Progianti, \& Spíndola, 2010).

A maternidade é uma vivência de transição ao papel materno, que só ocorre e finalizase com a adaptação a essa nova realidade. A mulher precisa dispor de recursos internos e externos (que nem sempre estão disponíveis), para superar as situações difíceis, que, aparentemente, são impossíveis sem o apoio social (Rapoport \& Piccinini, 2011; Zagoneli, Martins, Pereira, \& Athayde, 2003).

A gravidez pode propiciar maior união e aprofundamento no relacionamento do casal. Contudo, pode desestabilizar uma relação fragilizada, acarretando ameaça à estabilidade emocional (Maldonado, 2002). A transição atravessada pelos casais pode trazer transformações positivas ou negativas para o relacionamento conjugal, conforme a qualidade da relação. Caso exista um consistente envolvimento emocional, este é aprofundado, gerando respostas de apoio ao cônjuge. Contudo, se a transformação for impactante, e houver distanciamento afetivo, ocasionará a não preservação da conjugalidade (Menezes \& Lopes, 2007).

Além das transformações psíquicas e fisiológicas, também fatores socioeconômicos são alterados. Na sociedade moderna a mulher trabalha fora e contribui para a renda doméstica. Ela possui outras ambições além de ser mãe. A vinda de um filho interfere no desenvolvimento profissional da mulher, além de causar, muitas vezes, privações financeiras (Maldonado, 2002).

Rapoport e Piccinini (2011) relatam que em nossa sociedade é mistificada a vivência de ser mãe, visto apenas em seus aspectos positivos e gratificantes. Porém coexistem sentimentos ambivalentes. Além disso, todas estas questões podem gerar frustração, raiva e ressentimento (Maldonado, 2002)

A maternidade pode ser um período de transição existencial, implicando em transformações significativas, reestruturações e aprendizagens; sem necessariamente ser um período de crise. Contudo, se for vivenciado com sofrimento e conflito emocional, a mulher pode entrar em um período de crise: “num estado temporário de equilíbrio instável, em busca de novas soluções” (Maldonado, 2002, p. 24).

Conforme Sebastiane (1997), existem dois tipos de crise: as crises de evolução, que ocorrem em períodos do desenvolvimento como a gravidez e adolescência e; as crises 
traumáticas, que nos incidem de forma inesperada, como perdas e enfermidades por exemplo. A necessidade de nova adaptação surge em situações de ameaça e sofrimento.

\subsection{Gravidez de alto risco}

Se a gravidez por si só, pode ser considerada um desafio adaptativo, a gravidez de alto risco representa um desafio ainda maior, devido ao risco real em relação a saúde da própria gestante e de seu filho. O medo de ter uma criança anômala salienta a perda do controle sobre seu próprio corpo e gravidez, podendo gerar um aumento da ansiedade, que por sua vez, propicia o surgimento de problemas na evolução da gravidez, parto e da futura relação mãebebê (Tedesco, 1997).

Geralmente a gravidez caracterizada por alto risco traz o rótulo de ser diferente da gravidez normal, e, a gestante é muitas vezes tratada como uma doente que requer vigilância e cuidados excessivos. Todas estas questões fazem surgir uma crise neste período (Tedesco, 1997).

As gestantes de alto risco descrevem sentimentos de medo, angústia, ansiedade (Quevedo, Lopes, \& Lefèvre, 2006; Santos, 2005), depressão, insegurança, pavor e ciúmes (P. B. Santos, 2005). Coexistem sentimentos ambivalentes em relação a gravidez, que surgem de forma consciente e são reforçados pelo risco real de perda do bebê. Além disso, as gestantes sentem culpa, pois são corresponsáveis por seu estado físico devido a hábitos passados, sendo estes sentimentos, muitas vezes, ressaltados pelos discursos médicos (Santos, 2005).

Em gestantes de alto risco emergem dificuldades em manter os cuidados necessários à sua saúde e a do bebê, devido a ambivalência entre manter a gravidez ou manter sua própria identidade. Geralmente, os cuidados necessários à gestação acarretam limitações na rotina cotidiana (Quevedo et al., 2006; Santos, 2005). A gestação ocupa o lugar central na vida da gestante, que necessita mudar velhos hábitos, que agora, tornam-se ameaçadores. Aparecem no discurso das gestantes a preocupação em manter a gestação, porém suas atitudes não condizem com o discurso (Santos, 2005).

Por um lado, os cuidados no pré-natal na gestação de alto risco melhoram o prognóstico clínico e diminuem a mortalidade materna e perinatal, porém, por outro lado, aumentou a morbidade de desequilíbrios psicológicos. Internações longas ou sucessivas e outros cuidados físicos podem influenciar negativamente no relacionamento familiar (Tedesco, 1997). 
Em um estudo envolvendo 20 gestantes de risco, diabéticas (tipo 1 e 2) e cardiopatas, foi clarificado o sofrimento envolvido na vivência da doença crônica junto à gravidez, seja em relação a sofrimentos físicos, incômodos do tratamento ou limitações da vida social. Mesmo diante das dificuldades inerentes a internação e todo o sofrimento envolvido, as gestantes diabéticas e cardiopatas demonstram mecanismos de adaptação ao ambiente hospitalar. A doença crônica modifica o significado da maternidade, envolvendo sentimentos de superação de dificuldades (Quevedo et al., 2006).

A internação da gestante pode significar proteção e cuidado, mas também pode ser vista como uma libertação das responsabilidades domésticas e descanso. Caso a internação ocorra no final da gestação, provavelmente ela não voltará para casa antes do parto e outra pessoa terá que terminar os preparativos para a chegada do bebê (Szejer \& Stewart, 1997).

A gestante pode reagir a assistência médica pré-natal conforme seu psicodinamismo e as atitudes do médico ao exercer seu papel. A preocupação médica com exames e dados objetivos, pode ser sentida pela gestante como invasiva e amedrontadora e impedi-la de falar sobre suas preocupações, ou, pelo contrário, pode ser um momento para expressão de angústias. (Szejer \& Stewart, 1997).

A gravidez de risco remete a ferida narcísica da gestante e traz questionamentos sobre a própria capacidade de gerar um bebê saudável e a competência em ser mãe e pode interferir com a autoestima. As gestantes demonstram pouco investimento libidinal no feto, devido ao risco e a incerteza quanto a continuidade da vida do bebê (Santos, 2005). Por outro lado, Quevedo, Lopes e Lefèvre (2006), salientam que a gestante de alto risco atribui ao bebê o significado de ser especial, gerando alta expectativa diante do futuro bebê, devido a impossibilidade de gestações futuras ou dificuldades prévias (abortos anteriores). Além disso, hipotetizam que muitas mulheres negam a gravidade da sua doença e engravidam, muitas vezes com contraindicação médica, e carregam a fantasia de que gerar e dar à luz a um bebê perfeito seria uma indicação de que ela própria é saudável.

\subsection{Diabetes mellitus na gestação}

O Ministério da Saúde (2011) adverte que o Diabetes Mellitus (DM) é um problema de saúde pública, devido sua alta taxa de prevalência, que para as mulheres é de $6 \%$. A Sociedade Brasileira de Diabetes relata em suas diretrizes, que de 12\% a 13\% (ao ano) das gestantes desenvolvem diabetes mellitus gestacional (DMG); que $1 \%$ (ao ano) das gestantes possuem diabetes mellitus tipo 1(DM1) e; 2\% a 3\% (ao ano) das gestantes possuem diabetes mellitus tipo 2 (DM2) (Sociedade Brasileira de Diabetes, 2009). 
Durante a gestação ocorre um aumento nos níveis dos hormônios estrógeno, progesterona, cortisol, prolactina e a produção de lactogênio placentário humano. Essas alterações incidem sobre o equilíbrio metabólico podendo acarretar maiores dificuldades no controle glicêmico em gestantes com DM1 (Montenegro Jr et al., 2001).

O DM pré-gestacional, seja ele tipo 1 ou 2, é mais grave do que a DMG, afetando o organismo desde a concepção e em toda a organogênese, aumentando os riscos para a mãe e para o feto. Os riscos para o feto e neonatais ocorrem principalmente devido ao controle glicêmico inadequado e incluem: aborto espontâneo (Ray, O'Brien, \& Chan, 2001), má formação fetal (Cordero, Treuer, Landon, \& Gabbe, 1998; Eidem et al., 2010) e restrição de crescimento fetal (Cordero et al., 1998; Ray et al., 2001), além de hipoglicemia neonatal (Cordero et al., 1998; Jovanovic, 2004; Nold \& Georgieff, 2004), desconfortos respiratórios após o nascimento ou insuficiências respiratórias (Cordero et al., 1998) e complicações da prematuridade (Cordero et al., 1998) . Para a gestante também existem riscos aumentados, como por exemplo o agravo da retinopatia e/ou nefropatia pré-existente (Diabetes Control and Complications Trial Research Group, 2000).

Em um estudo foram avaliadas 50 gestantes portadoras de DM conforme o tipo de diabetes (DM1, DM2 e DMG) e constatou-se que mais de 90\% das gestantes, independente do tipo de DM, apresentam mau controle glicêmico. Apesar das gestantes com DM1 comparecerem mais precocemente ao consultório para a realização do pré-natal quando comparadas às gestantes portadoras de DM2 e DMG, o controle glicêmico satisfatório muitas vezes não era alcançado. É salientado a importância do bom controle glicêmico para a prevenção das complicações advindas com a DM, porém, na prática, o controle glicêmico satisfatório é dificilmente obtido. (Corrêa \& Gomes, 2004).

\subsection{Controle Glicêmico}

As gestantes diabéticas tipo 1 com o controle glicêmico adequado podem alcançar prognóstico semelhante à gestante não diabética, diminuindo a morbimortalidade fetal e as complicações geradas tanto pela hiperglicemia quanto pela hipoglicemia (Golbert \& Campos, 2008). Os índices de glicemia pré-prandial devem estar entre 60 e 95mg/dl, os valores de pico pós-prandial se encontrem entre 100 e 140mg/dl e em gestantes com maiores riscos de hipoglicemia os índices de glicemia de jejum não devem ser menores que 99mg/dl. (Manderson et al., 2003).

Enfermeiras da Clínica Obstétrica do HCFMUSP relatam que para a gestante com DM1 estar com o controle glicêmico bom ela não pode ter mais de $30 \%$ das medidas de 
dextro com valores fora dos índices desejáveis (valores alterados). A partir de 31\% de dextros com valores fora dos índices recomendados é considerado mau controle glicêmico. Salientam que este resultado é muito difícil de ser alcançado pois mesmo quando as gestantes com DM1 são internadas, com dieta e insulinoterapia rigorosamente controlada, a porcentagem de valores alterados pode ser superior a $30 \%$.

Estas profissionais contam que para manter os índices desejáveis é necessário seguir dieta nutricional específica, fazer a medição da glicemia com o glicosímetro e a aplicação de insulina conforme a prescrição médica. São realizadas sete medições no glicosímetro ao dia: em jejum, uma hora após o café, antes do almoço, uma hora após o almoço, antes do jantar, uma hora após o jantar e a última às três horas da manhã. A aplicação de insulina varia de paciente para paciente, ocorrendo no máximo seis vezes ao dia. Todas as medições de glicemia e injeções de insulina devem ser anotadas numa folha controle (ANEXO B). Durante a consulta pré-natal, os médicos comparam as anotações das gestantes realizadas na folha controle com a memória do glicosímetro para verificar a eficiência do controle e em seguida os valores dos dextros são digitados em uma planilha no programa Access que calcula automaticamente a média dos dextros, a porcentagem de valores alterados, a porcentagem de hipoglicemias graves, a porcentagem de hipoglicemias e a porcentagem de hiperglicemias.

De acordo com a portaria ${ }^{\circ} 2583$ (Ministério da Saúde, 2007), os medicamentos (insulina) e insumos (seringas, tiras reagentes e lancetas) são disponibilizados gratuitamente pelo Sistema Único de Saúde (SUS) para todos os pacientes portadores de DM. O glicosímetro também é disponibilizado pelo SUS para todos que necessitem de controle domiciliar. Conforme explicaram as enfermeiras do HCFMUSP, geralmente as gestantes com DM1 chegam ao pré-natal com conhecimento prévio na utilização do glicosímetro, pois possuem o aparelho e o controle glicêmico que já se faziam necessário previamente. Porém podem ser realizadas explicações de sua utilização caso necessário. As enfermeiras relatam que a gestante com DM1 deve registrar o resultado do exame na folha controle e, conforme o resultado obtido, calcula-se a dosagem da insulina que será aplicada através de injeção subcutânea.

\subsection{Psicodinamismo de gestantes portadoras de DM1}

O mau controle glicêmico pode ser visto, algumas vezes, como um evento ligado a gravidez atual, porém é necessário considerar se o descontrole já existia antes da gravidez ou se com este advento a mulher apresentou episódios patológicos agudos. Todavia os desequilíbrios podem estar ligadas a história da gravidez e ao contexto familiar (Szejer \& 
Stewart, 1997).

Em uma pesquisa (Wutke, 2009) foram comparados o psiquismo de 100 gestantes diabéticas com 100 gestantes não diabéticas. O autor relata que as gestantes diabéticas apresentaram maior regressão psíquica e predomínio do uso de defesas do ego imaturas e prejudiciais à eficácia adaptativa, além de sintomas de transtornos mentais como ansiedade, somatizações, irritabilidade e depressão. Descreve também os resultados positivos obtidos em grupos de sala de espera, nos quais as gestantes podiam se expressar e desta forma veicular seus medos e angustias que impedem condutas mais adaptativas.

Barbosa, Duarte e Santos (2012), em um estudo de caso, descrevem o atendimento de uma gestante com DM1, através de 5 sessões de psicoterapia breve de orientação psicanalítica. Relatam a importância para a paciente em se sentir vista, valorizada e acolhida em suas angústias.

Ferreira (2009), examinando Teste de Apercepção Temática de gestantes com DM pré-gestacional (tipo 1 e 2), encontrou 41\% de condutas instintivas, o que se equipara a respostas de crianças e adolescentes, e, atribui este resultado, ao início precoce da preocupação materna primária ${ }^{1}$ (Winnicot, 1988). Relata a necessidade de proteção e cuidado destas gestantes e o desejo em reviver os cuidados maternos.

Maia e Araújo (2004), salientam a importância do atendimento psicológico e multidisciplinar para os pacientes diabéticos - gestantes ou não. Demonstram a possibilidade de uma relação direta entre o controle glicêmico e aspectos psicológicos destes pacientes. Costa (2002), estudando o HTP em dois pacientes diabéticos insulinodependentes, encontrou mecanismos de defesa menos evoluídos como a negação, anulação e isolamento, além da preponderância do instinto de morte.

Apesar da pesquisa de Heleno (2000) não ter sido realizada com gestantes e nem pacientes com DM1, foi encontrado resultados interessantes. A autora pesquisou 30 pacientes com DM2, escolhidos randomicamente de uma amostra de 113 pacientes. Os pacientes foram agrupados conforme a qualidade (bom ou mau) do controle glicêmico. Todos tiveram sua adaptação diagnosticada conforme a Escala Diagnóstica Adaptativa Operacionalizada

${ }^{1}$ Segundo Winnicott (1960), as modificações corporais oriundas da gestação transformam o olhar da mulher sobre si mesma, dando início às transformações psíquicas que se seguem. A mudança fisiológica sentida, atrai a atenção da mulher para seu interior aumentando o interesse por si própria. Este interesse é transferido para o feto em crescimento dentro do seu útero. As mães começam a se identificar com o feto ainda em formação, de modo que com o nascimento do bebê, atingem uma compreensão das necessidades de seu filho recém-nascido (Winnicott, 1960, 1988). Esta identificação normal é o estado de “preocupação materna primária”(Winnicott, 1988) 
(EDAO). Também foi utilizado como instrumento o Teste de Relações Objetais. Foi demonstrada relação entre a qualidade de controle glicêmico e a eficácia da adaptação do paciente. Quanto mais eficaz a adaptação, melhor o controle glicêmico, assim como o inverso, quanto mais ineficaz a adaptação, pior o controle glicêmico. Além disso, nos pacientes com DM2 e mau controle glicêmico foram percebidas organizações patológicas (Steinar, 1997), instinto de morte predominante e respostas mais ineficazes. A presença e intensidade das organizações patológicas nos diabéticos tipo 2 com mau controle glicêmico, impediram o tratamento médico e a melhora na qualidade de vida. A identificação projetiva maciça e a paralisação impedem o contato com o mundo interno e sentimentos, diante de estímulos angustiantes (Heleno, 2000).

Conforme Heleno (2000), as respostas dos pacientes com mau controle glicêmico foram em sua maioria pouquíssimo adequadas e permeadas por fantasias de objetos internos persecutórios ou idealizados. No setor Orgânico (Or), a maioria dos pacientes não aceita a perda do corpo saudável, porém geralmente a s/p do setor Or tem origem no setor Afetivorelacional (AR). No setor Sociocultural (SC) as respostas foram preponderantemente pouquíssimo adequadas e relacionadas ao isolamento social. Pacientes frequentadores de igreja, relacionaram a doença a vontade de Deus e demonstraram culpa persecutória ao invés da aceitação da situação. No setor Produtividade (Pr) os pacientes demonstraram perdas significativas, devido aos sintomas causados pela doença, demonstrando o efeito do setor Or agindo no Pr (Heleno, 2000). Simon (2005) observando os resultados obtidos por Heleno (2000), e recalculando-os estatisticamente, encontrou o seguinte resultado: 100\% dos indivíduos com Adaptação Eficaz ou Adaptação Ineficaz Leve mantêm um bom controle glicêmico, enquanto $100 \%$ dos indivíduos com Adaptação Ineficaz Severa ou Grave não mantêm um bom controle glicêmico. Contudo, indivíduos com Adaptação Ineficaz moderada têm 50\% de chance de manter um bom ou mau controle glicêmico.

\subsection{Sistema Diagnóstico Adaptativo Operacionalizado}

Simon (1989, 2005), relata que a EDAO surgiu como instrumento diagnóstico com o objetivo de facilitar a triagem em programas de prevenção, para pessoas consideradas dentro da "normalidade” (mais especificamente estudantes universitários), e que não caberiam nas classificações psiquiátricas clássicas. Além de diagnosticar o indivíduo conforme sua adaptação, também é possível identificar se a pessoa se encontra em crise adaptativa.

Posteriormente o autor amplia o sistema diagnóstico e o intitula de Sistema Diagnóstico Adaptativo Operacionalizado (SISDAO) incluindo, além da EDAO, as 
entrevistas clínicas, realizadas conforme os setores que norteiam a EDAO permitindo uma utilização bem mais ampla da escala, o planejamento da PBO e seu prognóstico (Simon, 2005).

\subsection{Escala Diagnóstica Adaptativa Operacionalizada - EDAO-R}

A primeira fase da PBO é finalizada com o diagnóstico adaptativo realizado conforme a EDAO (anexo A). Esta escala baseia-se no conceito de adaptação, definida por Simon (1989, p.14) “como sendo o conjunto de respostas de um organismo vivo, em vários momentos, a situações que o modificam, permitindo a manutenção de sua organização (por mínima que seja) compatível com a vida”.

Através da EDAO, pode ser avaliado funcionalmente os dados psíquicos, tanto do presente quanto do passado do indivíduo e seu prognóstico. Com as informações obtidas nas entrevistas iniciais é classificada a maneira pela qual se dá a adaptação, percebendo as respostas como ineficazes ou eficazes (Simon, 1989, 2005).

Para o indivíduo se adaptar é necessário encontrar soluções para as dificuldades da vida. Essas soluções são avaliadas conforme três critérios: primeiramente se a solução resolve o problema, em segundo lugar se a solução encontrada traz gratificação ao indivíduo e, por fim, se acarreta ou não conflitos intrapsíquicos e/ou ambientais (Simon, 1989, 2005).

Simon (1989, 2005) classifica três tipos de adequação às situações-problema: adequado se resolve o problema, com gratificação para o indivíduo e sem conflitos intrapsíquicos e/ou ambientais; pouco adequado quando resolve sem gratificação para o indivíduo, mas sem conflitos ou resolve com satisfação e com conflitos ambientais e/ou intrapsíquicos; e pouquíssimo adequado quando a solução não traz gratificação e ainda gera conflitos. Se o indivíduo não consegue encontrar solução à situação-problema atual é considerado em crise adaptativa.

Para a classificação, conforme a EDAO são considerados quatro setores nos quais podem haver situação-problema. a) Setor afetivo-relacional (A-R): engloba o conjunto de sentimentos, atitudes e ações intrapessoais ou interpessoais; b) setor produtividade ( $\operatorname{Pr}$ ): refere-se ao conjunto de sentimentos, atitudes e ações relacionadas a atividade produtiva (trabalho, estudos entre outros) do indivíduo; c) setor sociocultural (S-C): compreende o conjunto de sentimentos, atitudes e ações relativos a sociedade, aos valores e costumes da cultura; e d) setor orgânico (Or): abrange a anatomia e fisiologia do indivíduo, além de tudo que está relacionado ao seu organismo, como a saúde, higiene, alimentação, seus sentimentos e ações em relação ao seu corpo (Simon, 1989). Recebem pontuação para a classificação 
diagnóstica apenas os setores A-R e Pr, enquanto os setores Or e S-C são avaliados qualitativamente (Simon, 1997).

As pontuações diferem entre os setores A-R e Pr (ANEXO A), devido suas influências na adaptação geral do indivíduo. O setor A-R por ter maior influência, recebe pontuação mais alta: Se for adequado recebe três pontos, se for pouco adequado recebe dois pontos e se for pouquíssimo adequado recebe um ponto. Já o setor Pr por ter menor influência na adaptação global do indivíduo, recebe pontuação mais baixa: Se for adequado recebe dois pontos, se for pouco adequado recebe um ponto e se for pouquíssimo adequado recebe meio ponto (Simon, 1997).

Resultam cinco classificações diagnósticas (ANEXO A): Grupo um (G1) - Adaptação Eficaz - cinco pontos, Grupo dois (G2) - Adaptação Ineficaz Leve - quatro pontos, Grupo três (G3) - Adaptação Ineficaz Moderada - três ou três e meio pontos, Grupo quatro (G4) Adaptação Ineficaz Severa - dois ou dois e meio pontos e, Grupo cinco (G5) - Adaptação Ineficaz Grave - um e meio pontos (Simon, 1997).

A adaptação de um indivíduo é dinâmica, sofrendo alterações conforme o surgimento de novas situações-problema (Simon, 2005) e as soluções adotadas para resolve-las. As mudanças podem ocorrer em períodos estáveis, de forma gradual, ou ainda, podem ser em períodos críticos, acorrendo de forma brusca. É possível, durante as entrevistas, perceber se um paciente, mesmo que em período estável, tenderá passar por um período crítico devido a um fator inevitável. Essa alteração pode acarretar um aumento ou diminuição na adequação do indivíduo (Simon, 2014).

Segundo Simom (2005), é possível fazer um gráfico cartesiano, no qual são quantificados os fatores ambientais (fatores externos) e os fatores constitucionais (fatores internos) do indivíduo, e, pode-se prever, com alguma exatidão, quais os indivíduos mais propensos a um bom ou mau prognóstico. O modelo de geometria analítica engloba os conceitos de constituição e ambiente como fatores causadores de transtornos mentais, contribuindo na eficácia das soluções encontradas.

A partir da teorização da geometria analítica, Simon (2005) propõe uma formula que auxilia na realização do prognóstico do paciente: $G=C+A$. Nesta equação etiológica o $G$ corresponde ao grupo adaptativo no qual o paciente está diagnosticado, C representa os fatores constitucionais (internos) e A corresponde os fatores ambientais (externos).

Como fatores constitucionais temos o instinto de vida e o instinto de morte, que em constante flutuação influenciam as soluções encontradas pelos indivíduos. Ambos são necessários à sobrevivência do ser humano, contudo, a preponderância do instinto de morte 
caracteriza pior prognóstico em PBO. Da mesma forma quanto mais desfavorável o ambiente, pior será o prognóstico adaptativo. Em contrapartida quanto mais intenso o instinto de vida e/ou quanto mais acolhedor o ambiente, melhor o prognóstico (Simon, 2005).

O autor apresenta, ainda, que, salvo exceções, quanto maior a eficácia da adaptação melhor será o prognóstico deste paciente em PBO. Assim, pacientes do G5 - Adaptação Ineficaz Grave - tem mau prognóstico, pacientes do G4 - Adaptação Ineficaz Severa - tem prognóstico reservado, os pacientes do G3 - Adaptação Ineficaz Moderada - possuem prognóstico regular, os pacientes do G2 - Adaptação Ineficaz Leve - tem bom prognóstico e os pacientes do G1 - Adaptação Eficaz - possuem prognóstico muito bom. Ainda dentro de cada grupo, quanto mais intensos os instintos de vida e/ou quanto mais benéfico o ambiente no qual a pessoa está inserida, há uma tendência a um melhor prognóstico (Simon, 2005).

Com o auxílio da PBO, o paciente pode modificar mais facilmente o ambiente e a forma com que se relaciona com este, do que modificar seus instintos de morte e de vida, o que torna mais suscetível ao sucesso a PBO realizada em pacientes com quadros leves e moderados, ou seja, que possuam instinto de vida mais intensos e/ou ambientes mais favoráveis (Simon, 2005). Indivíduos com distúrbios crônicos e com quadros graves podem se beneficiar da técnica, desde que o foco seja as situações-problema atuais (Simon \& Yamamoto, 2009).

\subsection{Crise Adaptativa - sua prevenção e prognóstico}

Segundo Simon (2005), a crise adaptativa se dá quando o indivíduo está diante de uma situação-problema inédita e significativa, para a qual é difícil encontrar uma solução. Enquanto uma solução não for encontrada a crise permanece, tornando-se cada vez mais aguda. A solução encontrada pode não ser adequada; ainda assim, mesmo se for pouquíssimo adequada, o sujeito consegue solucionar a crise, pelo menos momentaneamente.

Crise adaptativa é definida por Simon (1989) como o aumento ou diminuição significativos no espaço do universo pessoal ${ }^{2}$ de um indivíduo. Quando postergada, a crise é “incubada” e pode eclodir em um momento posterior (Simon, 2011). É de importância fundamental atender o indivíduo nos períodos de crise, pois, é neste momento, que existe maior motivação para receber ajuda e realizar mudanças na eficácia da sua adaptação. O autor descreve diversas s/p e seus potenciais riscos para crise adaptativa. Eventos com forte

\footnotetext{
${ }^{2}$ Universo pessoal é a totalidade formada pelo indivíduo (psiquismo e organismo) somado aos objetos externos (pessoas, bens materiais, espirituais e realidade sociocultural).
} 
impacto traz maior possibilidade de crise, como, por exemplo, a gravidez do primeiro filho e o nascimento do bebe. (Simon, 2011).

Se a crise adaptativa ocorre por redução do espaço do universo pessoal é denominada crise por perda, enquanto que a crise por aquisição seria o acréscimo do espaço do universo pessoal do indivíduo (Simon, 2011).

Nas crises por perda (ou expectativa) há predominância de sentimentos onipotentes de culpa pela perda, ou seja, a pessoa se culpa pela perda vivida (ou esperada). Pode ocorrer este tipo de crise no caso de morte de alguém significativo, ou perda de emprego considerado importante para a pessoa, rompimento de relacionamentos amorosos, a descoberta de uma doença grave, entre outros. No atendimento em $\mathrm{PBO}$, nas crises por perda, o procedimento correto é ajudar o paciente na elaboração da culpa, para consequentemente, poder aceitar a perda e, gradualmente, poder interessar-se por outros objetos. O terapeuta pode, através de sugestão, isentar a culpa do paciente (Simon, 2011).

As crises por aquisição (ou expectativa), podem ser consequência de uma situação nova (ou sua expectativa), nas quais podem prevalecer sentimentos de inadequação. $\mathrm{O}$ indivíduo não se acha capaz o suficiente para enfrentar a situação e possui, muitas vezes, insegurança diante do desafio. Há pessimismo ou expectativa de fracasso inevitável. Todos estes sentimentos são causadores de angústia persecutória e, há um risco de fuga da situação ansiógena. No atendimento em PBO, nas crises por aquisição, o procedimento correto é ajudar o paciente a superar seus sentimentos de inadequação, inferioridade e insegurança.

Em PBO, o terapeuta deve concentrar-se primeiramente na situação crítica, podenda atender mais de uma vez por semana conforme a urgência do caso. Dar o acolhimento adequado e evitar que o paciente desista, precipitadamente, do processo terapêutico. Depois de encontrada uma solução, mesmo que pouquíssimo adequada, deve-se dar continuidade a PBO como em qualquer caso. Realizar as entrevistas, distinguir as situações-problema, inclusive a nuclear, realizar a compreensão psicodinâmica, e assim por diante, como será visto em sequência.

\subsection{Entrevista Clínica Psicológica}

As entrevistas clínicas psicológicas podem ser preventivas, caso o contato inicial seja feito pelo psicólogo, sem que os sujeitos busquem pelo atendimento (Simon, 1989). Esta modalidade de entrevista permite contatar o paciente antes do período patogênico; ou, se já estiver no período patogênico, na fase patogênica precoce (Leavell \& Clark, 1965). 
Quando não é o próprio paciente que busca a ajuda psicológica, não há uma queixa inicial por parte dele, pela qual, tradicionalmente, se inicia uma entrevista clínica. A incerteza do porquê da entrevista, gera no paciente fantasias, que, muitas vezes, podem ter conteúdos persecutórios. Tendo em vista estas questões, pode-se iniciar a entrevista perguntando: "Você sabe por que está aqui? ”. Assim, tem-se a oportunidade de corrigir e complementar a resposta do paciente, minimizando possíveis fantasias persecutórias (Simon, 1989).

A postura do psicólogo entrevistador deve ser ativa e diretiva, aprofundando os aspectos que achar necessários e pode também utilizar da interpretação quando houver necessidade de desfazer resistências (transferência negativa), visando alcançar maior colaboração do paciente (Simon, 1989).

Durante as entrevistas conforme o SISDAO é importante verificar todos os fatores ${ }^{3}$ que influenciam na adequação da adaptação do indivíduo. Conhecer a história de vida do paciente, desde seu nascimento, e, a partir dela são levantadas hipóteses sobre os padrões psicodinâmicos. Devem ser feitas conjecturas sobre os fatores objetais internos ${ }^{4}$, se positivos ou negativos, investigando também como os fatores externos ${ }^{5}$ influenciaram soluções adequadas, pouco ou pouquíssimo adequadas (Simon, 2005).

\subsection{Psicoterapia Breve}

Bellack e Small (1980), relatam que a intervenção psicoterápica em situações de emergência é indicada para: a) prevenção (impedir que um problema esporádico torne-se uma desordem psíquica, que um desequilíbrio agudo torne-se um transtorno crônico ou se o quadro já for crônico, que este não caminhe para incapacitação definitiva) e b) tratamento de

\footnotetext{
${ }^{3}$ Os fatores podem ser internos ou externos. Dentre os fatores internos existem os orgânicos e os psíquicos. Orgânicos são relacionados ao corpo e seu funcionamento. Os fatores internos psíquicos podem ser fatores tensionais (as necessidades, desejos e emoções), defensivos (cisão, negação, repressão e sublimação) ou fatores objetais. Os fatores externos podem ser materiais (questões financeiras, ambiente e mundo físico) ou ainda pessoas reais.

${ }^{4}$ Fatores objetais ( $\mathrm{f} / \mathrm{Oi}$ ): relações dos objetos internos com o ego. Podem ser positivos (f/Oi+) ou negativos (f/Oi -), assim como persecutórios (f/Oi --) ou extremamente idealizados (f/Oi++). Pode ocorrer também de um objeto bom tender a mau $(\mathrm{f} / \mathrm{Oi}+\rightarrow-)$, assim como um objeto mau tender a bom $(\mathrm{f} / \mathrm{Oi}-\rightarrow+)$.

${ }^{5}$ Fatores externos (f/e): referem-se a situações objetivas externas ou pessoas significativas, que interferem na resolução da s/p. podem ser positivos $\left(\mathrm{f} / \mathrm{e}^{+}\right)$se benéficos a pessoa, ou negativos (f/e-) se prejudiciais ao indivíduo. O conceito de objetos externos (f/Oe) difere de mundo objetivo, pois no f/Oe há impressões subjetivas do indivíduo. O mecanismo de identificação projetiva (Klein, 1946/2006), por exemplo, pode alterar profundamente a percepção do indivíduo sobre os objetos externos. Assim, um objeto externo que à primeira vista é f/Oe+, pode ser sentido como negativo. Conforme a percepção do indivíduo e se tornar f/[ (Oe+) -]. Pode também um f/Oe- ser sentido com Oe+, tornando-se f/[ (Oe-+] devido a idealização. Quando a projeção é excessiva, o f/Oe pode tornar-se persecutório f/[ (Oe) - -] por estar impregnado da destrutividade do próprio indivíduo. Contudo se a idealização for maciça, resultará em f/[ (Oe) ++].
} 
dificuldades adaptativas e de situações de crise para as quais sejam suficientes a psicoterapia breve. Nas vivências traumáticas uma psicoterapia breve pode ser efetiva impedindo desenvolvimento de transtornos mentais crônicos e adaptações não adequadas.

Os métodos psicoterapêuticos breves podem e devem ser utilizados em pacientes em crise para que tenha o melhor efeito, mas também podem ser utilizados em outros pacientes para que um maior número de pessoas possam aderir ao tratamento (Malan, 1981). Sifneos (1989) relata que em alguns casos, quando o indivíduo está maduro para receber uma intervenção, uma única entrevista pode resultar em grande benefício para o paciente, não mais sendo necessária a psicoterapia. Ressalta a importância da aliança terapêutica em psicoterapia breve, para obter cooperação do paciente para que traga informação significativa; e, se for forte o suficiente, mesmo se houver transferência negativa e contratransferência negativa, porém com o objetivo em comum de solucionar os problemas pode haver êxito no trabalho psicoterápico.

Fiorini (1993), aponta para três eixos fundamentais em psicoterapia breve: incentivar a ativação das funções egóicas, dentro de uma relação de vínculo terapêutico adequado e manter o foco na situação vital específica. Manter o foco na situação vital também é relatado por Knobel (1986) e Malan (1981).

Prochaska (1995), define seis estágios de mudança, nos quais os pacientes se encontram no início do tratamento, e podem estar mais ou menos propensos a mudanças psicológicas e comportamentais, conforme a consciência do problema existente e o grau de motivação. Estes estágios não são fixos e se modificam dinamicamente durante o tempo e o percurso da psicoterapia. Apesar do autor ter desenvolvido estas ideias para uma amostra específica (tabagistas), ele próprio salienta que podem ser utilizadas para inúmeras populações, neste caso, gestantes com mau controle glicêmico. Os estágios são: précontemplação, contemplação, preparação, ação, manutenção e término.

Pacientes no estágio de pré-contemplação são os menos propícios a mudança, visto que não tem consciência de sua patologia, e, portanto, não sentem necessidade de ajuda. São geralmente encaminhados por médicos ou outro profissional, ou ainda, buscam psicoterapia por pressão de familiares. Já no estágio de contemplação, existe consciência da existência de um problema, porém não há nenhuma mudança de atitude para a modificação do problema. No estágio de preparação, há alguma tentativa de modificação na atitude, porém esta não permanece, ocorrendo recaídas. No estágio de ação, efetivamente há alteração na atitude e no comportamento, contudo, há risco de recaídas. Já no estágio de manutenção, no qual o indivíduo permanece ao menos 6 meses com as mudanças obtidas, mas ainda é necessário um 
grande esforço para manter-se sem recaídas, e, por fim há o estágio de término, no qual a modificação é efetivamente mantida sem esforço e gasto de energia (Prochaska, 1995)

\subsection{Psicoterapia Breve Operacionalizada}

A psicoterapia Breve Operacionalizada (PBO) é uma modalidade de psicoterapia breve com referencial teórico na psicanálise e na teoria da adaptação. A PBO é realizada em duas fases: na primeira são feitas entrevistas psicológicas clínicas em número necessário para realizar o diagnóstico adaptativo e planejar a PBO; e, a segunda, é a fase terapêutica, com número de sessões que pode variar de uma a no máximo 12 sessões. O diagnóstico adaptativo é feito conforme a Escala Diagnóstica Adaptativa Operacionalizada (EDAO) (Simon, 2005).

Durante as entrevistas clínicas psicológicas é importante verificar as situaçõesproblema $^{6}$ existentes, estabelecer a conexão existente entre elas, em quais setores da EDAO elas se encontram e qual será a situação-problema nuclear. Investigar o histórico das situações-problema: quais as soluções encontradas, quando ocorreram, as pessoas significativas envolvidas, como, porque aconteceram e como foram resolvidas. A partir destas informações, será realizado o planejamento da PBO e serão formuladas interpretações teorizadas para as situações-problema nuclear e as consequentes (Simon, 2005).

A PBO foi idealizada para suprir a necessidade de processos terapêuticos rápidos e objetivos, compatíveis com os orçamentos institucionais e com o aumento da demanda por psicoterapia, ocasionada pela popularização da busca de ajuda psicológica e consequente sobrecarga dos serviços de saúde pública (Simon, 2010).

A PBO utiliza recursos técnicos específicos:

a) A interpretação teorizada, principal ferramenta técnica da PBO. A interpretação teorizada se fundamenta na teoria psicanalítica e na história pregressa do paciente, compreendida durante as entrevistas iniciais. Através do conhecimento do psicodinamismo do paciente, podemos entender seus complexos inconscientes. São estes complexos os indutores

\footnotetext{
${ }^{6}$ A situação-problema (s/p) é caracterizada por uma situação nova e significativa para o indivíduo, para a qual ele necessite encontrar uma solução que não pode ser adiada por muito tempo. A resolução desta questão, mesmo que frustrante ou conflitiva, implica na diminuição da tensão existente e a não resolução culmina em uma crise adaptativa. Quanto melhor o histórico do indivíduo em encontrar soluções adequadas, maior a probabilidade dele encontrar uma nova solução adequada para esta s/p, baseado em seu repertório adquirido em experiências anteriores, com a ajuda de sua criatividade e bom senso. Para uma pessoa que comumente encontra soluções pouquíssimo adequadas haverá maior dificuldade em encontrar uma solução adequada à nova s/p, baseada em seu reduzido repertório. Geralmente neste caso há uma defasagem e distorções na percepção devido ao alto índice de identificações projetivas que deterioram a criatividade. A menos que haja uma intervenção psicoterápica, possivelmente ele se encontrará em um ciclo vicioso de soluções pouco e pouquíssimo adequadas (Simon, 2005).
} 
das repetições e distorções da atualidade, influenciando negativamente na adaptação do indivíduo. Uma interpretação teorizada correta recebida pelo paciente e admitida, possibilita insights permitindo que conflitos inconscientes se tornem conscientes encaminhando-o para a adoção de soluções mais adequadas e coerentes com sua realidade interna e externa (Gebara, 2009; Simon, 2005).

b) Na PBO a interpretação é feita, fundamentalmente, na relação extra transferencial (cotransferência ${ }^{7}$ ), na qual a interação entre o paciente e outras pessoas importantes em sua vida é trabalhada na psicoterapia. Pode-se interpretar a cotransferência, em seus aspectos defensivos e gratificantes, favorecendo descobertas sobre o inconsciente e sobre as fantasias do paciente relacionadas ao seu passado e refletidas no presente (Simon, 2005).

Uma pesquisa sobre a eficácia terapêutica da interpretação teorizada na PBO (Gebara, 2009), tornou visível sua eficácia no tratamento da PBO. Dos 30 sujeitos do grupo experimental, 86,66\% obteve melhora na eficácia adaptativa e 13,33\% não obteve alteração de grupo adaptativo. O grupo controle demonstrou que não houve evolução espontânea, com 86,66\% da amostra permanecendo no mesmo grupo adaptativo. Esta pesquisa comprovou, ainda, que a interpretação teorizada possui validade científica.

No estudo realizado por Gebara, Rosa, Simon e Yamamoto (2004) sobre a eficácia terapêutica da interpretação teorizada na PBO em situações emergenciais foram encontrados resultados significativos. Em $80 \%$ dos casos, no diagnóstico inicial foi detectado crise adaptativa e através da PBO foi possível desfazer este quadro. Apresentaram melhoras na adaptação 90\% dos sujeitos, evoluindo de grupo diagnóstico.

Conforme Simon (1989), no atendimento a pessoas em crise adaptativa, a PBO focaliza primeiramente a situação crítica, auxiliando o indivíduo a encontrar solução para a crise. Independentemente de estar ou não em crise, o objetivo é a melhora adaptativa do indivíduo, ajudando-o a encontrar soluções mais adequadas às situações-problema atuais, através de interpretações teorizadas formuladas previamente com base nas conjecturas psicodinâmicas compreendidas nas entrevistas.

Na PBO a postura do psicólogo é ativa e diretiva. Portanto não são estimuladas as associações-livres, exceto aquelas relativas às situações-problema. A posição corporal do psicoterapeuta e paciente é face a face. Não é estimulada a neurose de transferência, porém a

\footnotetext{
${ }^{7}$ Quando ocorre uma cotranferência o objeto em interação é percebido de forma distorcida por ser depositário de identificação projetiva, para atender as necessidades do indivíduo (desejo, impulso, angústia ou defesa). Estas distorções influenciam na adequação do indivíduo e na percepção realista das ações e intenções das pessoas.
} 
transferência negativa deve ser interpretada assim que surgir para evitar um possível impasse terapêutico ${ }^{8}$ (Simon, 2005).

\subsection{Campo de pesquisas em EDAO e PBO}

Foram realizadas buscas por literaturas acadêmicas no portal de busca integrada SIBI (Sistema integrado de bibliotecas Universidade de São Paulo), nas bases de dados BVSpsi, PsycBOOKSc, PsycARTICLES, PsycINFO, Scopus, e no Web of Knowledge que abrangessem a utilização de psicoterapia como técnica terapêutica no atendimento à gestante com DM, através do cruzamento dos seguintes termos: psicoterapia (psycotherapy), diabetes (diabetes) e gravidez (pregnancy). Foram recuperados 4 trabalhos relevantes (Barbosa, Duarte, \& Santos, 2012; Ferreira, 2009; Hayden et al., 2012; Valle, 2008), contudo, apesar de englobarem tratamentos psicológicos em gestantes diabéticas, nenhum objetivou a melhora do controle glicêmico.

Barbosa, Duarte e Santos (2012) buscaram compreender o psicodinamismo de uma gestante com diabetes melittus; Ferreira (2009) verificou se os sentimentos envolvidos na gestação de alto risco interferem na preocupação materna primária; Hayden et al (2012) teve como objetivo determinar os efeitos de depressão gestacional em mulheres portadoras de diabetes melittus e os efeitos no desenvolvimento de recém-nascidos; enquanto Valle (2008) buscou entender as vivências de gestantes com diabetes gestacional. Na busca realizada por Santos, Honda, Santeiro e Yoshida (2013) não foram encontradas pesquisas nacionais ou internacionais sobre o atendimento de gestantes com DM através da PBO.

Também não foram encontradas pesquisas que tenham utilizado a EDAO como instrumento no diagnóstico adaptativo de gestantes com DM1. Contudo, diversos estudos têm utilizado a EDAO como instrumento, para pesquisa científica de outros tipos de amostra. Esta tem se mostrado de grande utilidade para avaliação diagnóstica em amostras com peculiaridades diversas: (Bomfim, 2010; Heleno, 2000; Neder \& Simon, 2004; Santana, 2010; Tamagnini, 2009; Valentim, 2010; Yamamoto, 2004; Yamamoto \& Simon, 2006; entre outros).

Alguns estudos apontaram que o uso da PBO possibilitou aos pacientes lidar com a crise adaptativa na qual se encontravam, sem prejuízos para o nível adaptativo, como por exemplo Younes, (2011); Younes, Lessa, Yamamoto, Coniaric e Ditzz (2010) e Simon e

\footnotetext{
${ }^{8}$ Conforme Freud (1913), a ambivalência de sentimentos do paciente em relação ao terapeuta é esperada, mas se a transferência for essencialmente negativa, o tratamento torna-se impossibilitado.
} 
Yamamoto (2008). Estes trabalhos descrevem a melhora dos pacientes, com crescimento, amadurecimento e o enfrentamento da crise de forma adequada.

Bechara (2011), em sua dissertação, encontrou resultados significativos da PBO no atendimento de um paciente com DM1. Descreve a melhora da eficácia adaptativa do paciente. Foram realizadas oito entrevistas iniciais. O diagnóstico foi de adaptação ineficaz severa e, após 12 sessões de psicoterapia breve operacionalizada, e seis meses para a entrevista follow-up, o diagnóstico foi adaptação ineficaz leve.

\subsection{Justificativa}

Estes estudos recentes demonstram a importância do atendimento psicológico às gestantes com DM. Sendo a PBO uma técnica que pode instrumentalizar o psicólogo na difícil tarefa de enfrentar as exigências de um atendimento hospitalar, com rapidez e qualidade na assistência; considerando que a gestação pode ser um período de crise e que o DM neste momento pode ampliar os sentimentos ambivalentes das gestantes, demonstra-se a importância de estudar em profundidade as possibilidades e limites da PBO em gestantes com DM1. Tanto a Escala Diagnóstica Adaptativa Operacionalizada (EDAO) quanto a PBO são excelentes instrumentos preventivos que podem ser utilizados para a melhora da eficácia adaptativa e durante as crises, atuando de forma precoce e eficaz.

A pouca quantidade de pesquisas realizadas na área demonstra a necessidade de psicólogos pesquisadores que possam contribuir para o incremento cientifico deste tema. Inicialmente houve uma tentativa de limitar a busca, concentrando-a em trabalhos científicos que continham apenas o termo psicoterapia. Contudo, devido à pouca quantidade de pesquisas relevantes optou-se pela substituição deste termo por psico*, que inclui outros sufixos, abrangendo assim mais pesquisas.

Meu intuito de pesquisar as possibilidades e os limites da PBO aplicada a gestantes com DM1 foi fortalecido durante a pesquisa bibliográfica realizada sobre o assunto. A tese de doutorado de Heleno (2000), na qual foram pesquisados pacientes com DM2 (já descrita na Introdução), os resultados me levaram a crer que poderia ser muito útil o estudo, devido à grande importância das gestantes com DM1 manterem o bom controle glicêmico e a clara demonstração da relação entre a qualidade de controle glicêmico e a eficácia da adaptação do paciente.

Considerando-se o conteúdo exposto na Justificativa e na Introdução, tem-se que é de grande valia o desenvolvimento de técnicas que sirvam como instrumento para o diagnóstico preventivo e tratamento precoce desse tipo de população - gestantes com DM1 e mau 
controle glicêmico, impedindo que ocorra queda da eficácia adaptativa ou colaborando para o enfrentamento da crise de forma adequada, auxiliando as gestantes a solucionarem este quadro sem maiores prejuízos na sua adaptação global, além de, possivelmente, melhorar em seu controle glicêmico da gestante. A finalidade desta pesquisa é o de contribuir para o incremento científico da prática psicológica, estudando a PBO enquanto técnica terapêutica que pode beneficiar esta população, e consequentemente favorecer a saúde do futuro bebê.

\subsection{Objetivos}

\subsubsection{Objetivo geral}

Conhecer as possibilidades e limites da PBO no tratamento de gestantes portadoras de diabetes mellitus tipo 1 com mau controle glicêmico.

\subsubsection{Objetivos específicos}

1. Comparar o diagnóstico adaptativo das gestantes, antes e após a PBO, para verificar, se, durante esse período, ocorreram nelas mudanças adaptativas.

2. Averiguar se houve alterações no controle glicêmico das gestantes antes, durante e após a PBO.

3. Investigar se, dentre as gestantes, houve crise adaptativa; e, se houve, como foram as soluções encontradas para a mesma. 


\section{MATERIAL E MÉTODO}

\subsection{Método}

Foi utilizado o método clinico-qualitativo. Este método é utilizado no contexto das Ciências do Homem e da Saúde, buscando conhecer a fundo as vivências dos indivíduos e entender o significado individual do fenômeno da doença para a pessoa. O interesse fundamental é o conhecimento do processo em si (na presente pesquisa a PBO), ou seja, como o objeto de estudo acontece e não o resultado final analisado estatisticamente. Trata-se de um estudo exploratório e descritivo; por tanto, cada caso será estudado em profundidade (Turato, 2005).

No método o pesquisador deve manter uma postura de acolhimento das angústias e ansiedades dos participantes da pesquisa. A posição corporal entre pesquisador e participante deve ser face a face, o pesquisador deve incentivar as trocas afetivas, escutar atentamente a fala dos sujeitos preocupando-se com os objetivos da pesquisa, ou seja questões ligadas ao tema saúde/doença e processos terapêuticos, sempre atento a comunicação corporal e/ou comportamental do sujeito (Turato, 2000).

A presente pesquisa é um estudo de caso único com quatro replicações, chamado também de estudo de casos múltiplos (Yin, 2001). Deste modo, a análise dos resultados será a comparação entre o diagnóstico e controle glicêmico da participante com ela mesma. As 
quatro replicações deram ao estudo maior peso científico e confiabilidade, pois demonstrou a possibilidade de repetição do estudo com resultados semelhantes. O estudo de caso, descritivo e exploratório, é muito utilizado para a compreensão de aspectos psicológicos (Yin, 2001).

\subsection{Material}

\subsubsection{Participantes}

As participantes foram as gestantes portadoras de diabetes mellitus tipo 1 que demonstraram interesse em participar da pesquisa. Apenas uma optou pela não participação, alegando não gostar de conversar com psicólogas. Foram estudados quatro casos de gestantes portadoras de DM1 e mau controle glicêmico. A amostra foi constituída por conveniência. Todas as participantes foram encaminhadas pelos médicos ou enfermeiras da Clínica Obstétrica do Hospital das Clínicas da Faculdade de Medicina da Universidade de São Paulo (HCFMUSP).

\subsubsection{Critérios de inclusão}

Foi adotado como critério de inclusão estar gestante, ser portadora de DM1 com mau controle glicêmico, possuir interesse em participar da pesquisa, não apresentarem outras complicações de natureza orgânica e/ou mental que pudesse interferir nos resultados deste estudo e não ter iniciado psicoterapia com as psicólogas da Clínica Obstétrica do HCFMUSP.

\subsubsection{Local}

As entrevistas e o processo psicoterápico ocorreram em salas reservadas que garantiram a privacidade, dentro do setor de diabetes da Clínica Obstétrica do HCFMUSP e designadas pelas enfermeiras. Excepcionalmente durante internação, o atendimento foi realizado na varanda da enfermaria, local mais privativo que o quarto e costumeiramente utilizado pelas psicólogas da Clínica de Obstetrícia do HCFMUSP.

\subsubsection{Instrumentos}

Os instrumentos utilizados foram os descritos na Introdução:

- Entrevista clínica psicológica,

- Escala Diagnóstica Adaptativa Operacionalizada (EDAO),

- Psicoterapia Breve Operacionalizada (PBO).

\subsubsection{Procedimento}


Ao conhecer a Profa. Dra. Rossana Pulcineli Vieira Francisco, e ser convidada por ela a realizar a coleta de dados no HCFMUSP, fui conhecer o Laboratório de Diabetes Prégestacional da Clínica Obstétrica e assistir à palestra ministrada às gestantes com DM1. Fui apresentada e conversei com as enfermeiras que cuidam do pré-natal de risco e com os médicos da Clínica Obstétrica HCFMUSP, que se prontificaram a me encaminhar as gestantes com DM1 e que apresentavam mau controle glicêmico. Para evitar algum tipo de interferência na pesquisa, eram gestantes que estavam iniciando o pré-natal no citado Laboratório de Diabetes e ainda não haviam passado em consulta com as psicólogas da Clínica Obstétrica.

No primeiro contato com as gestantes era apresentada a pesquisa e averiguado sobre seu interesse em participar da pesquisa. Apenas uma gestante não demonstrou interesse em participar, relatando não gostar de falar com psicólogas. Esta foi excluída do estudo. Para as quatro gestantes participantes do estudo foi lido e explicado o Termo de Consentimento Livre e Esclarecido. Conforme a disponibilidade de horário da gestante era, iniciada, de imediato, a primeira entrevista clínica psicológica; ou, agendada para a terça-feira seguinte, dia em que ocorre o pré-natal das gestantes com DM1. As entrevistas e as sessões de psicoterapia, foram transcritas (ao término das mesmas) e supervisionadas por dois profissionais reconhecidamente capacitados.

Foram realizadas de duas ou três entrevistas, conforme a necessidade, nos moldes do SISDAO, para o diagnóstico adaptativo operacionalizado e planejamento da PBO. O número de sessões utilizadas para PBO foi definido conforme o diagnóstico adaptativo e a situaçãoproblema existente ou situações-problema existentes. O número de sessões de PBO variou de três a dez atendimentos.

Em contrato terapêutico foram comunicadas a situação-problema circunscrita e quantas sessões seriam realizadas. As entrevistas e as sessões terapêuticas tiveram duração de 45 minutos e frequência de uma vez por semana. As entrevistas e o processo psicoterápico foram realizados pela própria pesquisadora. Após a finalização da PBO e depois do follow up, foram novamente realizados os diagnósticos conforme a EDAO.

O primeiro diagnóstico ocorreu após as entrevistas e antes da PBO; o segundo, após o processo psicoterápico; e, o último, após a entrevista de follow up. A evolução do controle glicêmico foi acompanhada semanalmente, e, para análise do controle foi demonstrado em gráficos conforme a fase do atendimento (entrevista, PBO e follow up). O diagnóstico adaptativo foi elaborado de acordo com os critérios e as recomendações propostas por Simon (1989) em seu livro “Psicologia clínica preventiva. Novos fundamentos”.

Após os casos detalhados ocorreu a elaboração da análise e discussão dos resultados, 
com todos os casos conjuntos. A análise dos resultados foi obtida através da comparação entre o diagnóstico adaptativo operacionalizado realizado antes, depois da PBO e no follow up; ou seja, foi verificado se houve ou não mudanças na adequação das soluções que vinham sendo adotadas pelas gestantes antes e após a PBO; e, se existiram, se elas foram ou não positivas em relação a eficácia adaptativa, e ainda, se elas se mantiveram (follow up).

Paralelamente ocorreu o acompanhamento da evolução do controle glicêmico durante todo o processo, até a última entrevista follow up, através das análises dos dextros feitas em planilha Microsoft Access, pertencente ao prontuário informatizado das pacientes. Houve consultas aos prontuários (em papel e informatizado) das gestantes conforme a necessidade de verificação da condição médica e obtenção de informações.

\subsubsection{Análise dos aspectos éticos}

Em se tratando de pesquisa que envolve seres humanos, o projeto foi submetido à apreciação do Comitê de Ética em Pesquisa do Instituto de Psicologia da Universidade de São Paulo conforme estabelece a resolução n466/12 do Conselho Nacional de Saúde. O projeto foi também submetido ao Comitê de Ética em Pesquisa da Clínica Obstétrica do HCFMUSP. A participação na pesquisa não envolverá qualquer custo financeiro para as participantes voluntárias. O Termo de Consentimento Livre e Esclarecido foi elaborado de acordo com as especificações e exigências do HCFMUSP, visto que esta é a instituição coparticipante na qual será realizada a coleta de dados. 


\section{RESULTADOS}

Os resultados foram organizados a partir dos dados de cada uma das gestantes, e encontram-se descritos a seguir - Quadro 1. Estes dados foram obtidos nas entrevistas, que verificaram a análise psicodinâmica de cada uma delas, e incluem ainda a evolução da PBO (nas pacientes em que foram realizadas) e os diagnósticos adaptativos. Os nomes atribuídos a cada uma das participantes são fictícios.

Quadro 1 - Características gerais das participantes da pesquisa

\begin{tabular}{|c|c|c|c|c|}
\hline Participante & Idade & Escolaridade & Estado civil & Tempo gestacional \\
\hline Ana & 33 & Superior & Solteira & $20^{\circ}$ semana \\
Beatriz & 24 & $2^{\circ}$ completo & Solteira & $20^{\circ}$ semana \\
Cecília & 40 & Superior & Casada & $8^{\circ}$ semana \\
Denise & 37 & Superior & Casada & $12^{\circ}$ semana \\
\hline
\end{tabular}

Ana, Cecília e Denise possuem escolaridade superior completa. A idade das participantes variou entre 24 e 40 anos. A média de idade foi de 33,5. A média da idade gestacional no início dos atendimentos foi de 14,5 semanas de gestação. Apenas Cecília e Denise iniciaram o pré-natal precocemente. Ana e Beatriz descobriram tardiamente a gravidez, e, consequentemente, o pré-natal foi iniciado com a gravidez já avançada. As gestantes são casadas ou solteiras em igual número (quadro 1).

Quadro 2 - Características do DM1 e do controle glicêmico nas fases da vida. 


\begin{tabular}{|cc|ccccc|}
\hline Casos & Início do & \multicolumn{4}{|c|}{ Controle Glicêmico } \\
\cline { 3 - 6 } & DM1 & Infância & Adolescência & Vida Adulta & Gestação \\
\hline Ana & 5 anos & bom & mau & mau & mau \\
Beatriz & 9 anos & bom & mau & mau & mau \\
& & & & & \\
Cecília & 23 anos & Não & Não & mau & mau \\
& & portadora de & portadora de & & \\
& & DM1 & DM1 & mau & mau \\
Denise & 7 anos & bom & mau & mau \\
\end{tabular}

Cecília desenvolveu DM1 na fase adulta e Ana, Beatriz e Denise desenvolveram na infância. Conforme relatos, a dificuldade no controle glicêmico surge no momento em que se tornam responsáveis pelo controle glicêmico.

Quadro 3 - Características gerais da vida reprodutiva das participantes

\begin{tabular}{|c|c|c|c|c|c|}
\hline Participante & $\begin{array}{c}\mathbf{N}^{\circ} \text { de } \\
\text { filhos }\end{array}$ & Gestação & $\begin{array}{c}\text { Abortos } \\
\text { Prévios }\end{array}$ & $\begin{array}{c}\text { Planejamento } \\
\text { Familiar }\end{array}$ & $\begin{array}{c}\text { Uso de } \\
\text { anticoncepcionais }\end{array}$ \\
\hline Ana & 0 & $1^{\circ}$ & 0 & Não & Não \\
Beatriz & 0 & $1^{\circ}$ & 0 & Não & Não \\
Cecília & 1 & $3^{\circ}$ & 1 & Não & Não \\
Denise & 0 & $1^{\circ}$ & 0 & Não & Não \\
\hline
\end{tabular}

Três das gestantes são primigestas, com exceção de Cecília que está na terceira gestação, teve um aborto anterior e possui um filho vivo. Todas apresentam ambivalência em relação a gravidez: nenhuma delas planejou a gravidez e nem faziam uso de métodos contraceptivos eficazes (quadro 3). O quadro 3 salienta a falta de planejamento familiar destas mulheres, sem utilização de métodos contraceptivos, apesar de relatarem que a gravidez não foi planejada e estarem cientes dos riscos de uma possível gravidez.

\subsection{Apresentação dos casos clínicos}

\subsubsection{Caso Ana}

\section{História pregressa}


Ana, 33 anos, mora em uma cidade pequena próxima a São Paulo. Trabalha em um cargo público de intermediação familiar e está cursando o último ano da Faculdade na área de humanas. Mora com os pais, um sobrinho e o irmão mais novo. No mesmo quintal, em uma casa separada, moram a irmã com o marido e dois filhos. Ana tem um noivo que reside em cidade próxima. Planejam se casar e construir uma casa no quintal da mãe de Ana. Ambos aceitaram bem a gestação que, apesar de não ser planejada, também não foi evitada. É católica e catequista. Conta que o padre e a comunidade católica aceitaram bem a gestação e que já era esperada, pois, segundo Ana, todos sabiam que namoravam há muito tempo.

Ana relata ser o esteio da família. É procurada para resolver questões familiares importantes e tomar decisões, e, ao mesmo tempo, mimada e tratada como a caçula, cheia de cuidados. Desde a infância ocorreu este vínculo de cuidados devido à diabetes. Foi diagnosticada aos 5 anos, durante a gestação do seu irmão mais novo. Conta ter sentido a gravidez por ser muito ligada à mãe. Relata ter bom controle glicêmico e que, com a gravidez, este tem melhorado e ficou adequado. Ana descobriu a gravidez na décima semana de gestação e estava na vigésima quando iniciaram as entrevistas.

\section{Diagnóstico adaptativo e análise dos setores que norteiam a EDAO antes da PBO.}

Foram realizadas três entrevistas clínicas iniciais. Ana trazia descrições e relatos superficiais e, concentrava-se em mostrar-se alegre e satisfeita em todos os aspectos de sua vida. Apesar dos dados não serem suficientes e/ou confiáveis pois a paciente não se mostrou disponível, foi diagnosticada no G1 - adaptação eficaz. Pontuação: cinco.

Este foi o primeiro diagnóstico realizado. A paciente não demonstra s/p a ser trabalhada, então optou-se por trabalhar questões relacionadas a perda de espaço do universo pessoal relacionada ao nascimento do bebê, situação potencialmente geradora de crise adaptativa para todas as mulheres. Nas sessões haveria uma tentativa de desfazer a transferência negativa e a baixa motivação, pois estes dois aspectos somados tornam o caso “impossível”.

\section{Setor A-R:}

Não apresenta s/p, solução adequada (soluciona o problema com satisfação e sem conflitos): Solteira, namora há 4 anos e sente-se realizando um sonho com a gravidez. Mantinha regularmente relações sexuais com o namorado, que dormia aos fins de semana em sua casa. Planejam o casamento e a construção de uma casa.

\section{$\underline{\text { Setor Pr: }}$}


Não apresenta s/p, solução adequada (soluciona o problema com satisfação e sem conflitos): A gestante está no último semestre da faculdade e relata gostar do trabalho, que já está dentro do campo que estuda. Gosta dos colegas de trabalho e sente-se satisfeita com sua profissão.

\section{$\underline{\text { Setor Or: }}$}

$S / p$ : crises de hipoglicemia e hiperglicemia

Solução: oculta dos outros o mau controle glicêmico, e, dessa forma é como se não existissem, solução pouquíssimo adequada (sem satisfação e conflitos ocultados): Durante as entrevistas a paciente relata ter um bom controle glicêmico na gestação, que este melhorou muito, e, por isso, os médicos diminuíram a insulina e sente-se feliz por fazer o controle glicêmico com afinco em prol da saúde do bebê.

Conjectura psicodinâmica: Existem conflitos ocultados pela forte defesa maníaca, visto que a paciente tem mau controle glicêmico (com mais de 50\% dos dextros alterados e crises de hipoglicemia grave), apesar de relatar ter controle satisfatório.

\section{Setor S-C:}

Não apresenta s/p, solução adequada (soluciona o problema com satisfação e sem conflitos): A paciente relata sentir-se bem com a gestação mesmo sendo solteira e catequista, pois sua gravidez foi aceita por todos os familiares, padre e comunidade católica não ocorrendo conflito externo.

\section{Compreensão psicodinâmica}

O diabetes de Ana está simbolicamente associado à perda do seio. Quando criança, a paciente puniu a mãe por engravidar novamente com uma dependência para sempre (diabetes). Foi a forma que encontrou de manter a atenção da mãe e, segundo ela, até hoje é cercada de cuidados e tratada como caçula. A paciente, abdica da própria saúde e desenvolvimento para manter, em fantasia, o seio materno. Esta fantasia é de uma pessoa com

fortes impulsos autodestrutivos e instinto de morte exacerbado. A psicoterapia é a possibilidade de desenvolvimento; porém, reage negativamente. Ela está no processo psicoterápico devido a encaminhamento médico e sem motivação. Ana faz oposição a qualquer coisa que favoreça seu desenvolvimento e crescimento. A menarca ocorreu aos 15 anos, tardiamente, mostrando o poder do inconsciente e a tentativa de manter-se dependente e infantilizada.

Demonstra superioridade, arrogância e controle onipotente com relação a família, noivo e terapeuta. Conta "mentiras” a si mesma - seja em relação a seu controle glicêmico, seja em outras situações geradoras de angústias. Projeta nos familiares e noivo seu medo de 
morrer, sua dependência e necessidade do outro, tornando assim, os familiares e o noivo responsáveis por sua saúde. Nega o mau controle glicêmico e é como se ele não existisse.

\section{Psicoterapia Breve Operacionalizada e sua evolução}

Durante as entrevistas e todo o processo psicoterápico foi possível perceber a transferência negativa da paciente na recusa em trazer material para ser trabalhado. O pouco material trazido, quando interpretado foi totalmente rejeitado. Não havia abertura ou brecha. Seus vínculos são permeados de persecutoriedade (assim como com a terapeuta), não pode confiar nas pessoas.

Foram planejadas três sessões de PBO com caráter preventivo. As interpretações teorizadas realizadas foram:

Para diluição da transferência negativa: "você tem dificuldade de confiar em mim, por medo de se machucar."

Não confiança X desmame: "Você ficou tão magoada e com raiva de sua mãe, do seio não ser mais só seu, que você não pode confiar em mais ninguém”

Interpretação teorizada para prevenção de crise com o nascimento do bebê: "É difícil dividir a atenção e o amor de sua mãe com outro bebê" (nascimento do bebê a fará reviver a situação vivida com o nascimento do irmão mais novo)

Durante a psicoterapia, Ana escondia informações importantes, relativas ao controle glicêmico, e seu relato não condizia com a realidade. Ao ser confrontada com dados objetivos da realidade a paciente mudava seu discurso e tentava justificar-se, negando estes fatos, o que deve ter acirrado a transferência negativa e, consequentemente, a persecutoriedade em relação a terapeuta.

Apesar de no convite para participar da pesquisa Ana tenha aceitado prontamente, quando se iniciam as entrevistas ela não demonstra preocupação ou interesse pelo processo terapêutico, que foi realizado por ter sido encaminhada pelo médico, como uma imposição, evitando trazer informações importantes, que possibilitariam um diagnóstico mais próximo a realidade na qual a paciente se encontra. A questão da falta de interesse e predisposição ao processo psicoterapêutico somada a transferência negativa, tornou o diagnóstico, a compreensão psicodinâmica e a terapia empobrecidas e divergentes da realidade psíquica da paciente.

\section{Follow up: diagnóstico adaptativo e análise dos setores que norteiam a EDAO.}

Diagnóstico adaptativo G3 - Adaptação Ineficaz Moderada. Pontuação: três e meio. 
É importante clarificar que não houve queda na eficácia da adaptação pois os conflitos existiam previamente, o que ocorreu foi a falta de informação necessária para um diagnóstico correto e condizente com a realidade.

Foram percebidas informações importantes após a finalização da PBO, durante a entrevista de follow up. No setor Pr, apesar de ser questionada nas entrevistas em vão, a paciente relatou que antes de assumir a função em que se encontra, trabalhava em um comércio e sofreu um acidente, impossibilitando assim a continuidade no trabalho, o que levou a se afastar do emprego e receber seguro saúde. Ela está sofrendo processo jurídico por estar recebendo do INSS o seguro saúde e ao mesmo tempo trabalhando e recebendo pelo seu novo emprego, um cargo público, o que é contra a legislação vigente. A paciente corre o risco de ter que devolver o dinheiro recebido do seguro. Este processo já estava em andamento durante as entrevistas e sessões de $\mathrm{PBO}$, mas quando questionada sobre os trabalhos anteriores ela não relatou estas questões e, possivelmente, por isso tenha se mostrado tão esquiva.

Esta nova informação revela a inadequação de Ana no setor Pr, e no setor SC pois existem conflitos externos com a sociedade. Ana está “enganando” a sociedade, driblando as leis vigentes em prol de vantagens pessoais.

Setor A-R: A eficácia da adaptação manteve-se a mesma do diagnóstico pós PBO. Adequado: Solução satisfaz sem conflitos. Pontuação 3,0.

\section{$\underline{\text { Setor Pr: }}$}

S/p: Ambivalência em relação ao pedido de demissão, quer parar de trabalhar, mas não quer deixar de receber o salário.

Solução: No dia que assinaria a demissão que pediu, "sofre acidente” de trabalho, ao mexer em caixas de produtos em uma estante alta sem o uso da escada, deixando uma delas cair sobre seu braço. Solução pouquíssimo adequada (sem satisfação e gera conflitos). Pontuação 0,5

Conjectura psicodinâmica: Reproduz o desmame, quer continuar mamando mesmo sem trabalhar.

\section{Setor Or:}

$S / p$ : valores de dextro alterados que aumentam os riscos para a paciente e para o bebê.

Solução: Esconde as dificuldades, e, é como se não existisse. Pouquíssimo adequado. Não traz satisfação e gera conflitos.

Conjectura psicodinâmica: Defesas rígidas impedem de entrar em contato com a realidade interna 


\section{Setor S-C:}

S/p: Recebimento indevido de licença saúde.

Solução: Aguarda o processo acreditando que está tudo bem. Solução pouquíssimo adequada (não traz satisfação e gera conflitos).

Conjectura psicodinâmica: Através de defesas maníacas rígidas, principalmente negação, protege-se das angústias e nega a realidade interna e externa.

\section{Figura 1 - Matriz gráfica do caso Ana}

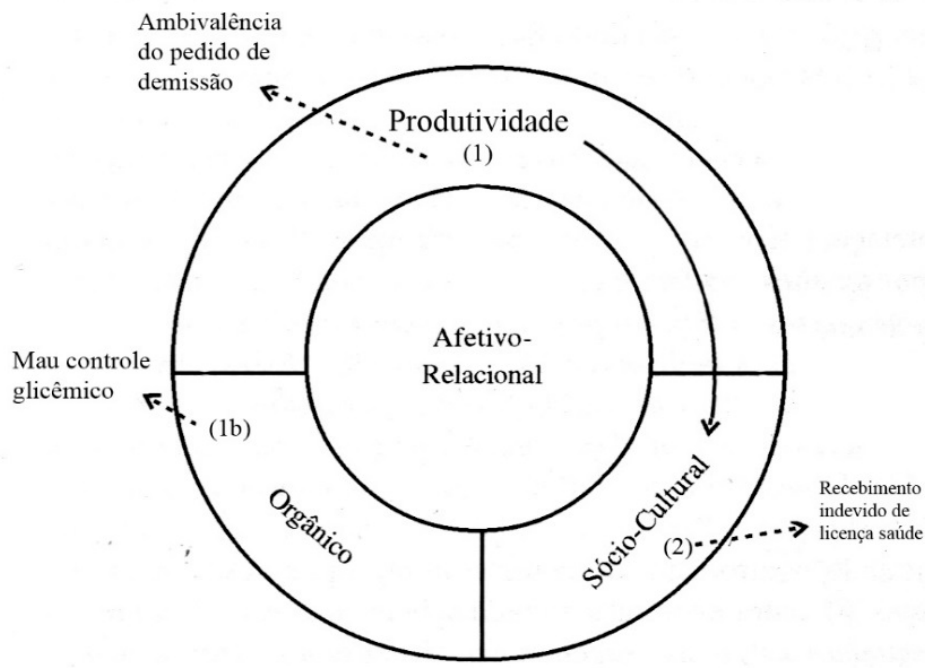

\section{Evolução do controle glicêmico}

\section{Gráfico 1 - Média do controle glicêmico nas diversas fases de atendimento}

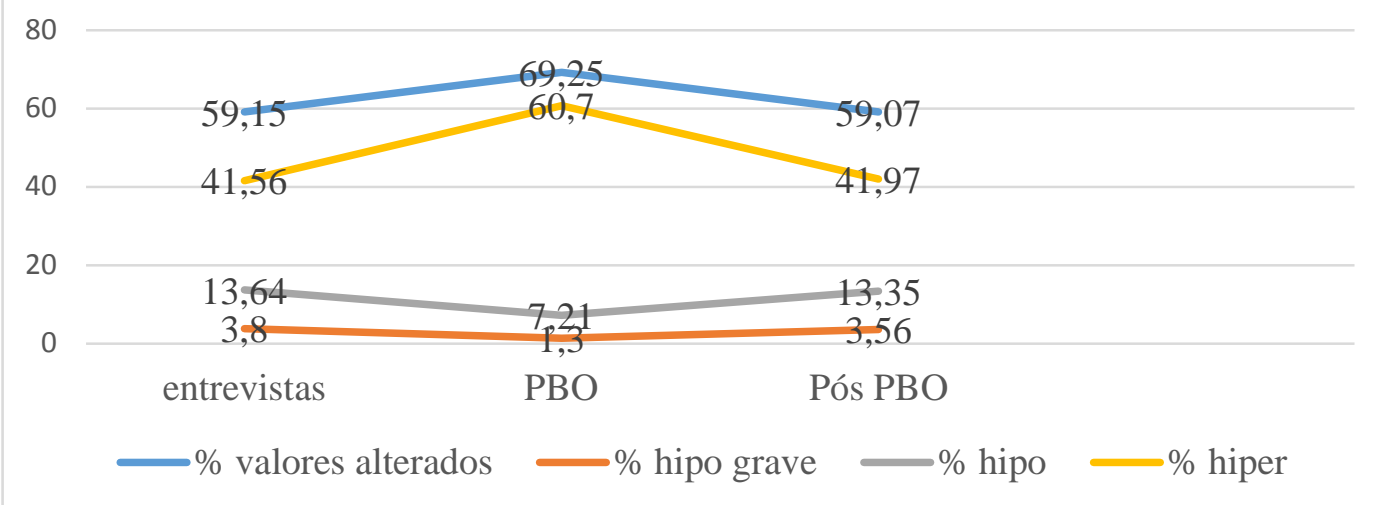

O gráfico 1 está mostrando que durante a fase da PBO houve um aumento nas medidas de hiperglicemias e consequente aumento da porcentagem dos valores alterados, ou seja, ocorreram mais medidas fora dos limites desejáveis. Já a quantidades de valores de hipoglicemias e hipoglicemias graves sofreram diminuição, o que é benéfico à paciente e ao 
bebê. Após o término da PBO, as medidas de glicemia parecem voltar à um patamar próximo a fase anterior das entrevistas.

\subsubsection{Caso Beatriz}

\section{História pregressa}

Beatriz estava na vigésima semana de gestação quando iniciamos as entrevistas. Com 24 anos, foi encaminhada pelo médico obstetra. Iniciou as entrevistas contando sobre seu relacionamento anterior que durou 3 anos. Relata que durante o último ano o namoro já estava desgastado; mas, não utilizou anticoncepcionais pois acreditava que iria se casar com ele. Quando descobriu mensagens indicativas de traição por parte do namorado se separou sem saber que estava grávida - teve dois meses de menstruação mesmo já estando grávida. Ao descobrir a gravidez estava na décima semana de gestação e namorando com o atual noivo que assumirá a paternidade do bebê. Não contaram a ninguém, além dos familiares mais próximos, sobre quem era o verdadeiro pai.

O ex namorado não sabe que é o pai biológico e este segredo foi um acordo entre Beatriz e seu noivo. Diz que sente muita vergonha do noivo não ser o pai biológico do bebê e que sempre imaginou que se casaria antes de engravidar. Relata que o noivo quer ser o pai, é carinhoso e passa segurança. Diz que ele não rejeitará o bebê, mas teme que ela própria o faça caso a criança se pareça fisicamente com o pai biológico. Diz ter muito medo que o bebê morra ou nasça com problemas de saúde - inconscientemente é o desejo dela - e que por "força maior" (sic) acabe sendo obrigada a revelar o segredo da paternidade da criança. Também tem medo que o bebê nasça com semelhanças físicas do pai biológico pois assim a mentira seria revelada. Tem pesadelos e é assombrada por estes medos.

Beatriz frequentou por um tempo a igreja evangélica com o noivo até a descoberta da gravidez. Depois, por medo de represálias da comunidade evangélica ao noivo - por tê-la engravidado - preferiu não frequentar mais.

\section{Diagnóstico adaptativo e análise dos setores que norteiam a EDAO antes da PBO}

Foram realizadas duas entrevistas iniciais, e diagnosticada conforme a EDAO no G3adaptação ineficaz moderada.

Setor A-R:

S/p nuclear (angustia principal): Culpa - parou de evitar a gravidez pois “imaginava” que iria se casar com o ex namorado - queria engravidar. 
Solução: diz que o noivo é o pai e o segredo faz com que o filho se torne do atual namorado, solução onipotente e mágica para a gravidez. Solução pouquíssimo adequada: Soluciona o problema, sem gratificação e com conflitos internos (pontuação: 1,0).

Conjectura psicodinâmica: Fantasia de incesto e o bebê é a prova da relação incestuosa, no inconsciente o ex é o representante do pai. A paciente utiliza como principal defesa a negação da paternidade do bebê e sofre as consequências dos seus atos.

S/p consequente: Castigo - O que acontecerá com o fruto dessa relação - Vai morrer, nascer morto, doente? Fantasias surgem em consequência da culpa, tornando-se fonte de angústia.

Auxiliar a paciente em fazer a ligação entre as duas s/p: a fantasia de que o bebê possa nascer defeituoso ou morto é consequência da culpa por ter engravidado. É o castigo.

Setor Pr:

Não apresenta s/p, gosta do trabalho de auxiliar administrativa e pretende especializarse em administração. Solução adequada: Soluciona com gratificação e sem conflitos (Pontuação: 2,0)

\section{Setor Or:}

S/p: Crises de hipoglicemia causam desconforto, alimentam fantasias de morte do bebê.

Solução: Se esforça para controlar corretamente a glicemia, mas sem sucesso. Mesmo durante as internações e com a colocação da bomba de insulina, mantém a dificuldade no controle. Solução pouco adequada (sem satisfação e sem conflitos).

Compreensão psicodinâmica: Conflitos no setor AR causam desequilíbrios glicêmicos.

\section{Setor S-C:}

$S / p$ : Medo de retaliações por parte da comunidade evangélica.

Solução: parou de frequentar a igreja com o noivo. Solução pouquíssimo adequada (sem satisfação e com conflitos psíquicos)

Conjectura psicodinâmica: Assim como no trabalho, Beatriz simplesmente deixa de frequentar a igreja.

Figura 2 - Matriz gráfica do caso Beatriz 


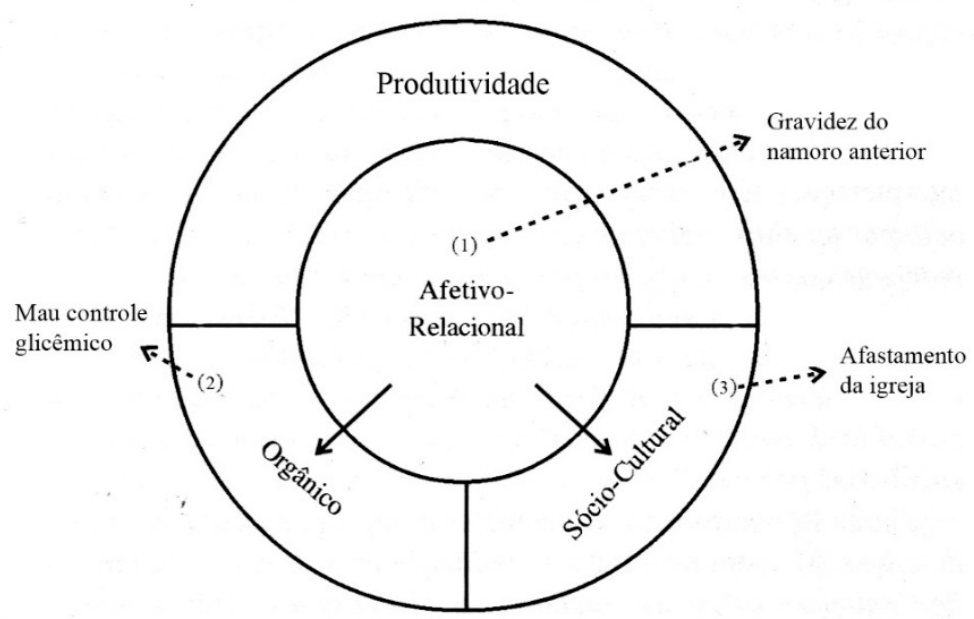

\section{Compreensão psicodinâmica}

A paciente apresenta um funcionamento psíquico característico da posição esquizo paranóide, utilizando como principal defesa a negação maníaca. Apresenta solução mágica para seus problemas e sobrepõe o que a angustia com uma idealização. O noivo, o pai é até si mesma enquanto mãe são idealizados.

A vergonha de Beatriz equipara-se à culpa. A culpa de Beatriz vem devido à onipotência - certeza que conseguiria se casar - não se preveniu, ela queria engravidar. Ela nega a realidade, pois relata em outra circunstância que o relacionamento estava desgastado há um ano, mesmo período que parou de usar anticoncepcionais. Possivelmente, ela acreditava que magicamente um bebê poderia recuperar a relação. A paciente, inconscientemente, tem o ex namorado como o pai - ambos tiveram um filho desconhecido o que torna seu filho fruto de uma relação incestuosa e ainda mais proibida e pecaminosa. A culpa é uma fonte constante de angústia. O que acontecerá com o fruto dessa relação? Vai morrer, nascer morto, malformado?

O bebê nascer com problemas é fantasia baseada na culpa. É o castigo. E os ataques que ela faz ao bebê (inconscientemente, descrevendo a gravidez como obstáculo ao casamento) reforçam estas fantasias. Beatriz cria uma fantasia perfeita como punição imposta pelo superego - pelo pecado cometido: além do bebê nascer doente, ela seria obrigada a revelar o segredo para salvar o bebê de alguma doença, ou seja, a punição seria dupla.

Mantendo o segredo da paternidade é como se o ex namorado nunca tivesse existido e o filho passa a ser do noivo. Ela sofre a consequência de seus atos, pois a realidade não pode ser alterada magicamente. O pai biológico continua a existir e a procurar a paciente e ela 
continua a sentir culpa, aparentemente ela gosta ainda dele, apesar de negar. Beatriz nega tudo que a angustia e sobrepõe com uma fantasia. O noivo é idealizado e a fantasia de que o noivo é bom é um recurso para evitar a angústia.

O fato dela continuar menstruando mesmo grávida demonstra o poder do inconsciente interferindo no funcionamento orgânico. Quando a paciente termina o namoro, a gravidez passa a ser indesejada, e, ela nega a realidade interna, a existência do bebê em seu útero.

\section{Psicoterapia Breve Operacionalizada e sua evolução}

Interpretações teorizadas:

Para diminuir a culpa: "Você parou de evitar a gravidez pois queria se casar e você se sente culpada porque você queria engravidar dele, para que ele ficasse com você”.

Para minimizar o medo que o bebê nasça anômalo: "a fantasia de que o bebê possa nascer defeituoso ou morto é consequência da culpa por ter engravidado. É o castigo”.

Medida suportiva educativa:

Para auxilia-la com seu medo de internação: “A internação não é um castigo pelo seu mau comportamento, é um benefício para sua saúde e de seu bebê”.

No total foram realizadas dez sessões de PBO conforme o planejamento. Destas, a paciente faltou em 3 sessões $\left(3^{\circ}, 6^{\circ}\right.$ e $\left.10^{\circ}\right)$. A primeira entrevista, as duas primeiras sessões de PBO e o follow up ocorreram na varanda da enfermaria da Clínica Obstétrica do HCFMUSP, em local confortável e privativo, devido internação para melhora do controle glicêmico.

Nas duas primeiras sessões de PBO as interpretações teorizadas não alcançaram o nível profundo, ela concorda com a culpa, mas, ao mesmo tempo nega a interpretação, relaciona a outros acontecimentos menos significativos, pois a paciente não aguenta se defrontar com a realidade. Na transcrição a seguir ela atribui a responsabilidade da culpa ao noivo.

Terapeuta: - "Pelas nossas conversas, na primeira entrevista você se emocionou quando falou que sente vergonha do seu noivo por ter engravidado de outro homem, e, fiquei pensando que isso está acontecendo porque você engravidou do seu ex por vontade própria, por ter achado que ele se casaria com você, e as coisas não saíram como você imaginava. Você se sente culpada por ter engravidado.

Paciente: “É me sinto culpada.... Eu nunca liguei para o que as pessoas pensam, mas tenho medo de que outros venham a saber e digam bobagem para ao meu noivo ou para mim. Ele não merece isso. É ruim já começar um relacionamento com um obstáculo...” 
As reclamações frequentes pela internação e a resposta dada a terapeuta demonstram os sentimentos ambivalentes em relação bebê que está trazendo complicações a sua vida, mas ela nega prontamente a terapeuta e se idealiza enquanto mãe, condição que a torna incapaz de ter sentimentos negativos em relação ao próprio filho.

Terapeuta: - "Você sente o bebê como um obstáculo para seu relacionamento? ”

Paciente: - "Não. O bebê não de jeito nenhum! Até porque ele está acima de tudo, jamais tomaria partido de um homem, o bebê vem primeiro. Mas a situação sabe, do bebê não ser do meu noivo. No início achei que fosse dele, mesmo sem termos transado, mas depois que soube que estava grávida de dois meses, fiquei arrasada...”

Mesmo com a internação, rigoroso controle e colocação da bomba de insulina, a glicemia está desajustada, o que demonstra a existência de conflito, angustia e insegurança. Chega a ser questionada a possibilidade da paciente não ser tratável devido a rigidez do mecanismo de defesa negação que aparece de forma intensa.

A paciente falta na terceira sessão, parece realmente que nenhuma interpretação surtirá efeito; e, a partir da quarta sessão, a paciente começa a assimilar as interpretações, a se aprofundar e conhecer os próprios sentimentos:

Paciente: - "Pensei no que conversamos e acho que você estava certa. Sinto culpa. E sabe que até melhorou. Quando eu falava nisso, chorava sem parar, era incontrolável. Falar com minha mãe com meu noivo.... Eu sempre começava a chorar e agora eu estou conseguindo falar nisso. Inclusive contei para minha melhor amiga. E nem chorei. Ela ficou feliz por eu ter depositado esta confiança nela. E disse que eu estava certa que a vida segue em frente e que eu tenho que fazer o que for melhor para mim e para o bebê. ”

Beatriz conta para uma amiga sobre seu ex namorado ser o pai biológico do bebê, como um esparramamento da culpa, uma forma que o superego encontrou para puni-la pois, está correndo o risco de ser descoberta ou, possivelmente, ela quer ser descoberta e ter o namorado de volta. Ela sente culpa por esconder do ex namorado seu filho. Além da culpa pela gravidez, criou uma complicação, culpa por não ter contado.

Na quinta sessão a paciente relata a fantasia de castigo pelo “crime cometido" (inconscientemente relação incestuosa) e o risco do bebê ser amaldiçoado por ser fruto de uma outra relação, esta interpretação é aceita pela paciente:

T: Você se sentiu culpada por ter engravidado do seu ex namorado e, o bebê nascer com problemas de saúde seria um castigo pelo que você fez. 
P: Nossa seria um castigo mesmo, principalmente se ele precisar do pai biológico para um tratamento médico. Tipo um castigo mesmo. Eu não quero falar. Mas acho que de seu ser diabética, gravidez de risco a gente se preocupa mais com o bebê ter algum problema.

T: O fato da gravidez ser de risco dá mais asas à imaginação, aumenta esse sentimento. Mas acredito que isso está relacionada a culpa. Seria um castigo pelo erro que cometeu.

P: O médico falou que o pior já passou, que o bebê está formadinho, tem todos os dedinhos do pé e da mão. Que há sim o perigo de ele ter hipoglicemia ao nascer se eu tiver durante a gravidez muita hiperglicemia. Que ele produzirá muita insulina. Disse também que assim que o bebê nasce, eles fazem o exame e se tiver em hipo eles cuidam e dá tudo certo. Mas mesmo assim eu penso que ele pode nascer com um problema de saúde. Mas não é só isso. Se ele for diabético, tudo bem a gente controla, cuida dele. O pior é se ele precisar do pai biológico para algum tratamento e eu ser obrigada a contar.... Isso é que é castigo. Mas se acontecer eu conto, pois o bebê está acima de tudo e eu faço o que for preciso para ele ficar bem.

Ela falta na próxima sessão, demonstrando dificuldade na aceitação da interpretação teorizada, como forma de desprezo da terapeuta e transferência negativa.

Na sétima sessão, além das interpretações realizadas, surge o medo de nova internação e esta questão também é trabalhada: fantasia de que a internação é castigo pelo mau comportamento. Este sentimento é reforçado pelo discurso médico, pois é usado como argumento e ameaça para que a paciente mantenha o controle necessário. É realizada medida suportiva educativa: internação não é uma punição, é um benefício, pois garantirá a sua saúde e de seu bebê.

Durante as próximas sessões continuam a serem trabalhadas as interpretações teorizadas, relacionadas a culpa (inconsciente) por esconder do ex namorado seu filho. A angustia é uma forma de se punir, é o castigo (inconsciente). Engravidou pensando que sabia o que ia acontecer (onipotência), que iria se casar com o ex namorado.

Elas são repetidas de diferentes formas, para que a paciente possa entrar em contato com seus sentimentos e amenizar a culpa. Beatriz demonstra a vontade de conversar sobre o assunto e traz estas questões à terapia.

A paciente criou para ela própria uma situação difícil, na qual é impossível não cometer erros, o que propicia a culpa. Se ela conta ao ex que ele é o pai, estará traindo e prejudicando o noivo que já contou a todos que é o pai; se ela não conta, estará prejudicando o ex e o bebê por impedir a convivência do pai com o filho. Foram trabalhadas interpretações para ela entrar em contato com seus sentimentos e minimizar a culpa, que existirá, ela queira, quer não, pois o fruto do erro está em seu ventre e nascerá, estará sempre presente para 
lembra-la do erro que acredita ter cometido. Também foram confrontadas as fantasias com a realidade para que a paciente perceba que são realmente fantasias.

Com a evolução da psicoterapia torna-se perceptível o efeito das interpretações teorizadas e os conflitos intrapsíquicos são minimizados. A paciente aos poucos conscientizase da escolha que fez e que a culpa por mentir vai existir, porém, bastante diminuída e bem menos angustiante. As fantasias não perturbam mais a paciente, que aceita melhor os pensamentos que surgem. No início da terapia chorava copiosamente ao conversar com a terapeuta ou com a família sobre o pai biológico da criança e, agora, o assunto pode ser discutido tranquilamente, inclusive com o noivo. Sente-se bem com a escolha que fez.

Beatriz havia relatado numa sessão anterior ter sonhos onde era atacada por leões e disse que eram o seu ex e sua família. Sentia-se assombrada pelos pesadelos. Conforme as interpretações teorizadas foram aceitas, a culpa amenizou e ela pode se sentir mais tranquila e segura, sem tantos medos e fantasias. Teve um novo sonho no qual os leões estavam calmos, do lado de fora da casa, em um campo de girassóis. Em relação ao bebê morrer ou nascer doente, a paciente não trouxe mais a terapia esta questão.

\section{Diagnóstico adaptativo e análise dos setores que norteiam a EDAO após PBO}

Foram realizadas dez sessões de PBO, e diagnosticada conforme a EDAO no G2adaptação ineficaz leve, crise postergada. Com o nascimento do bebê, pode ocorrer queda na adaptação, principalmente se o noivo se sentir ressentido de não ser o pai biológico do bebê e deixar de apoia-la, ou se se desentenderem de alguma forma.

Setor A-R:

S/p nuclear: Os conflitos são minimizados, em muito. Não é atormentada por pesadelos e conversa sobre o assunto com tranquilidade. O bebê está presente, para lembra-la constantemente do erro cometido, mas Beatriz consegue lidar com a situação. Solução adequada.

S/p consequente: A paciente não traz mais este assunto a terapia, e, ao confrontar com a realidade, de que o bebê é saudável, conforme os exames e relatos médicos, o conflito parece ter acabado.

\section{$\underline{\text { Setor Pr: }}$}

Neste setor não houve modificação, continua adequado.

$\underline{\text { Setor Or: }}$ 
Ocorre uma melhora no controle glicêmico, mas não o suficiente para caracteriza-lo como bom controle. Solução pouco adequada.

Setor S-C:

Continua a não frequentar a igreja com o noivo. Solução pouco adequada

\section{Follow up e diagnóstico adaptativo}

O follow up ocorreu 70 dias após o fim da PBO, 15 dias após o nascimento do bebê. Neste caso, durante o follow up, a paciente demonstrou ter entrado em crise adaptativa (por expectativa de perda), pois, com a proximidade do parto, a paciente descreve fantasias em relação a aparência física do bebê, como se ele pudesse nascer idêntico ao pai, e, desta forma, revelando o segredo; porém, com o nascimento, ela percebeu que o bebê se parecia com ela, o que a satisfez e solucionou a crise sem queda na eficácia da adaptação. Na entrevista de follow up Beatriz se mostra feliz e orgulhosa do bebê. Sem conflitos. O diagnóstico se mantém: $\underline{\mathrm{G} 2}$ adaptação ineficaz leve.

\section{Evolução do controle glicêmico}

Gráfico 2 - Média do controle glicêmico nas diversas fases de atendimento

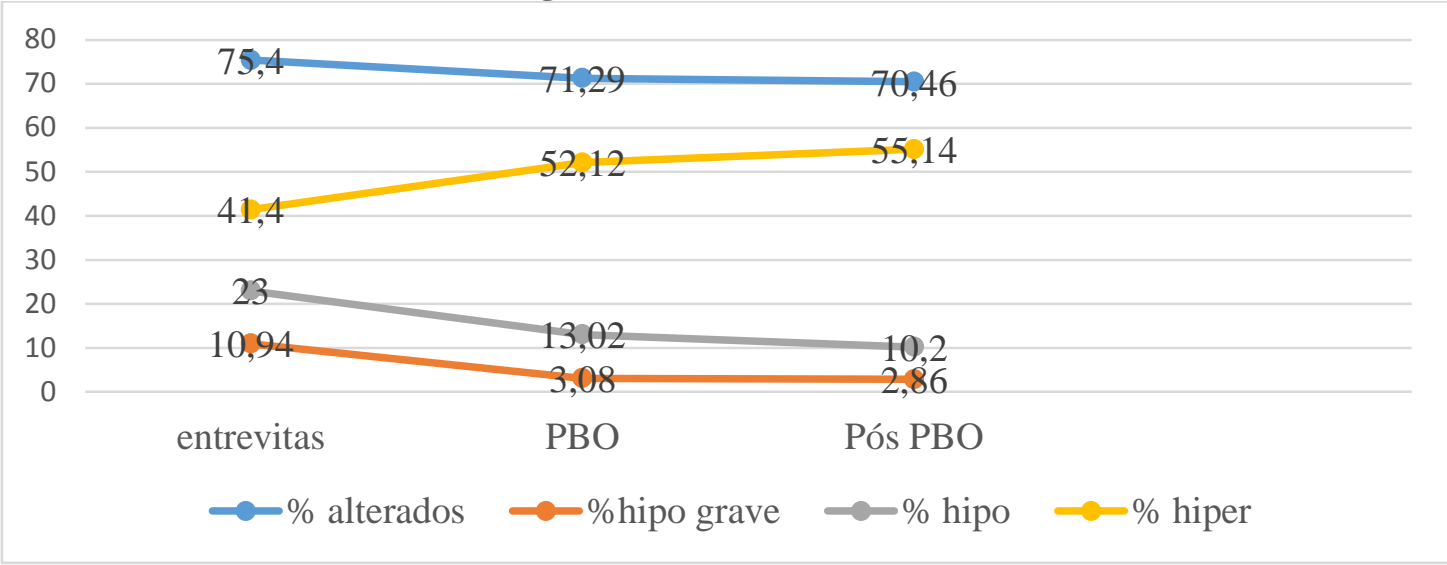

O gráfico 2 está mostrando que com o início da fase da PBO houve uma diminuição das medidas de glicemia fora dos níveis desejáveis, além da diminuição das medidas de glicemia em hipoglicemias e hipoglicemias graves. Já as porcentagens de hiperglicemias sofreram aumento. Com o fim da PBO, tanto os benefícios quanto os valores indesejáveis continuaram a aumentar, porém mais discretamente.

\subsubsection{Caso Cecília}

História pregressa 
Cecília, aos 40 anos, estava grávida de 8 semanas quando iniciamos as entrevistas. Relata medo e preocupações constantes com relação a saúde do bebê e aborto. Possui um filho de 11 anos, teve um aborto espontâneo na segunda gestação (há 6 anos atrás) e agora, sente-se mal física e psiquicamente devido a gravidez indesejada.

Casada com dependente químico recuperado há três anos, não planejaram nenhuma das três gestações e todas ocorreram da mesma forma, erro na tabelinha. Sente-se muito preocupada em relação as finanças, pois neste ano deveria trabalhar e conseguir empregos temporários na cozinha, para ano que vem abrir seu próprio negócio como confeiteira para pagar o financiamento da faculdade de gastronomia. Sente que o bebê impossibilitará a realização de seus planos. Fazia artesanato e participou de dois programas famosos de TV explicando como fazer. O negócio prosperava, mas começou a recusar trabalho por não poder produzir a quantidade necessária e acabou desistindo.

A paciente relata dificuldade em aceitar a gestação e não se sente preparada para ter mais um filho. Queixa-se de dores horríveis nas pernas, sono, fome, falta de ar. Também o controle glicêmico foi dificultado com a gestação e reclama do número de vezes que tem que medir, da contagem de carboidrato e do cálculo e aplicação da insulina.

Desenvolveu a diabetes aos 23 anos, quando era casada com o primeiro marido. Relata ter sido uma época de muito estresse devido a ciúmes constantes do marido e relacionamento ruim. Tem dificuldade com o controle glicêmico.

\section{Diagnóstico adaptativo e análise dos setores que norteiam a EDAO durante as entrevistas}

Durante as entrevistas: Diagnóstico G5 - adaptação ineficaz grave, em crise por expectativa de perda no setor Pr (pontuação: um e meio).

Ocorre uma melhora significativa na eficácia da adaptação com as entrevistas, diagnóstico após entrevistas: Diagnóstico G3 - adaptação ineficaz moderada. Pontuação: três.

Setor A-R:

S/p nuclear: se coloca constantemente em situação de risco, auto sabotagem (quando seus artesanatos ficam famosos e com grande procura ela desiste, quando seus planos profissionais estão se encaminhando e dando certo ela engravida, especializa-se em confeiteira mesmo precisando controlar o açúcar).

Solução: busca controle e organização, pede ajuda e moradia para a sogra: solução pouquíssimo adequada (soluciona o problema sem satisfação e com conflitos psíquicos e externos) Pontos: um. 
Conjectura psicodinâmica: Cotranferência na sogra da avó protetora: Desejo em reviver os anos felizes com amor.

Setor Pr:

S/p consequente: planos profissionais interrompidos devido a gravidez (acredita que terá dificuldade em conseguir empregos temporários em cozinha conforme a evolução da gravidez - trabalho pesado para gestante)

Em crise, por expectativa de perda.

Solução para a crise: permitiu-se desligar-se do feto e consequente aborto espontâneo (inconsciente), solução adequada (soluciona com satisfação e sem conflitos. Pontos: dois

Conjectura psicodinâmica: Devido a auto sabotagem, engravida, mas não quer o bebê. Já não havia investimento libidinal nele; e, por isso, o bebê não se desenvolve adequadamente. Apesar da paciente ter preponderante instinto de morte, neste caso, sobressaiu o instinto de vida (o marido dependente químico acaba de conseguir um emprego, mas não oferece estabilidade e, ela própria, não está preparada para ter mais um filho. O casal não possuía condições psíquicas e financeiras para cuidar de um bebê).

Setor Or:

$S / p$ : crises de hipoglicemia, dores e mal-estares diversos. Sofrimento psíquico com o mal-estar físico.

Solução: Tenta, sem sucesso, controlar adequadamente a glicemia: prova os doces que cozinha, faz as medições glicêmicas, mas não é o suficiente. Solução pouquíssimo adequada, sem satisfação e com conflitos.

Conjectura psicodinâmica: paciente com preponderante instinto de morte, se coloca em situação de risco constantemente, inclusive trabalhando como confeiteira.

Setor S-C: Não há s/p, não rela nenhum tipo de dificuldade com relação a sociedade. Adequado

Figura 3 - Matriz gráfica do caso Cecília 


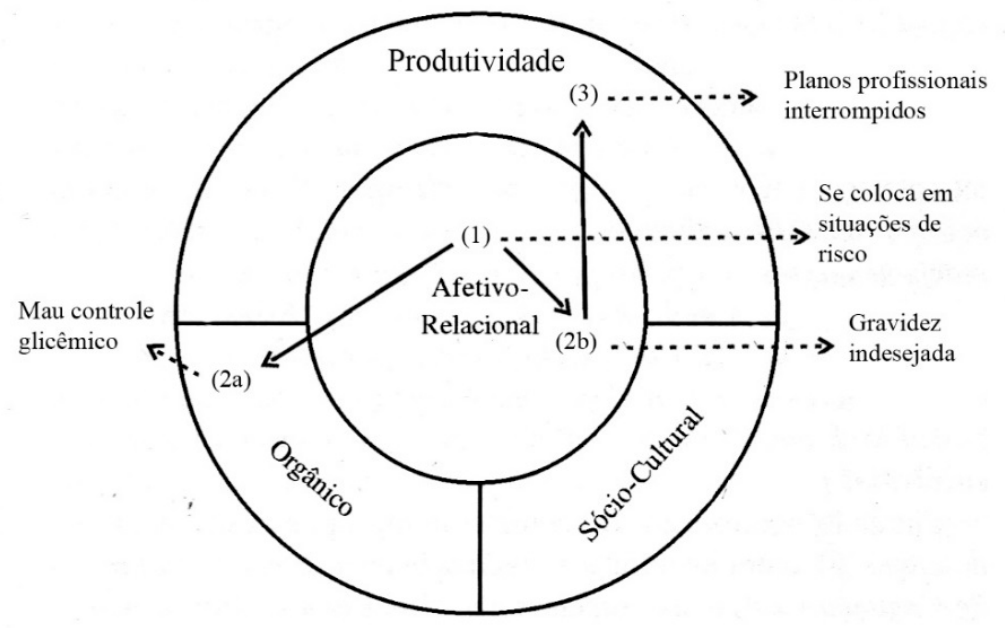

\section{Compreensão psicodinâmica}

A paciente demonstra a predominância do instinto de morte: quando sua vida começa a melhorar ela se auto sabota. Quando está se organizando, se auto desorganiza. Na vida profissional, quando seu negócio prospera ela simplesmente abandona e recusa os trabalhos, por acreditar que não será capaz de produzir o suficiente. Ela relata o desejo de independência e a dificuldade em alcança-la, isto se deve, principalmente, a auto sabotagem. Agora que sua vida começou a melhorar, e, colocaria em prática seus planos para prosperar, engravidou, prejudicando sua vida profissional.

Outra questão que demonstra a preponderância do instinto de morte são as frequentes situações de risco em que se coloca. Entre todas as opções possíveis escolheu como profissão a confeitaria, que exige experimentar as receitas açucaradas. Casar com um homem dependente químico, traz instabilidade, financeira e emocional. A forma de contracepção utilizada também é de risco, e mesmo tendo engravidado duas vezes desse modo, continuou a utiliza-la.

Quando criança, passou seus melhores anos morando com a avó paterna - apesar de seus pais morarem junto, só recebia os cuidados e carinho da avó - e reproduz esta situação, buscando controle, organização na casa da sogra. É visível a cotransferência com a sogra. Ela não é igual a avó, nem Cecília é uma menina que precise da organização da avó, pode organizar a própria vida. 


\section{Psicoterapia Breve Operacionalizada e sua evolução}

Durante as entrevistas Cecília relata prazer em estar na terapia e considera uma oportunidade. Diz que queria há muito tempo fazer psicoterapia, sente-se motivada e conseguimos boa aliança terapêutica. A PBO auxiliou como ambiente acolhedor, como fator externo positivo (Simon, 2005) favorecendo soluções mais adequadas. Neste caso, em conjectura, o ambiente acolhedor favoreceu a instinto de vida, e Cecília, que já não investia muita libido no feto, "permitiu-se" o aborto. Ao ver no ultrassom que o feto se desenvolvia inadequadamente (muito pequeno, órgãos pouco desenvolvidos e com poucos batimentos cardíacos) pode liberá-lo, sem culpa. Teve um aborto espontâneo na $10^{\circ}$ semana de gestação e, devido a desligamento do setor de obstetrícia houve a interrupção do processo terapêutico e encaminhamento ao setor de psicologia do HCFMUSP por ter interesse em continuar a psicoterapia.

\subsubsection{Caso Denise}

\section{História Pregressa}

Denise estava na $10^{\circ}$ semana de gestação do primeiro filho, aos 37 anos, quando fizemos a triagem. Ela e o marido achavam-se estéreis, ela devido a mioma anterior e ele sem motivos físicos. Pensavam em adotar uma criança. Quando souberam da gravidez, ficaram muito alegres com a realização do sonho.

Diabética desde os 7 anos, conta que na infância não sentia vontade de doces e inclusive temia come-los. Desde que se tornou responsável por sua saúde, aos 14 anos, tem mau controle glicêmico.

Após a separação amigável e sem explicação (os pais não brigavam e não deram justificativas, surpreendendo a paciente com o divórcio), quando Denise tinha 18 anos, o pai comerciário entrou em falência, ocasionando dificuldades financeiras para a família. Está muito preocupada em perder o emprego, pois, com a separação dos pais “virou o homem da casa”; e, depois que engravidou, começou a ter muita hipoglicemia, sente-se mal e falta constantemente para realizar o pré-natal. Em uma casa, no mesmo quintal, moram a mãe e irmã mais nova. Em uma edícula no fundo moram ela e o marido. Denise é a provedora de ambas as casas; e, agora que está gravida, sente vontade de dar tudo ao bebê.

Diz que trata a irmã de 30 anos como sua filha, como se fosse um “catatauzinho” (sic) ainda. Casada há um ano, ama seu marido e se sente feliz. Casaram-se com ele desempregado. Fez quatro anos de arquitetura antes da faculdade de pedagogia, mas abandonou o curso 
devido a um comentário do professor, de que seria uma péssima arquiteta. Relata ter se encontrado como professora e adora a profissão.

\section{Diagnóstico adaptativo e análise dos setores que norteiam a EDAO antes da PBO}

Diagnóstico: G4 - adaptação ineficaz severa. Pontuação: dois e meio.

\section{Setor A-R:}

S/p nuclear: Culpa pela separação dos pais

Solução: Assumiu o papel de "homem da casa", provendo sua casa e a da mãe sozinha. Possui marido não provedor e família dependente. Solução pouco adequada (sem satisfação e sem conflitos). Pontos: dois

Conjectura psicodinâmica: se sentiu tão culpada pela separação dos pais, que assumiu o papel “de homem da casa”. A irmã é tratada como filha aos 30 anos e casa-se com marido desempregado.

\section{Setor Pr:}

S/p consequente: medo constante em perder o emprego.

Solução: mesmo quando se sente mal, sem condições de trabalhar e durante crises de hipoglicemia (com medo e desmaios), continua a dar aula apesar da diretora manda-la para casa descansar. Solução pouquíssimo adequada (não há satisfação e tem com conflitos psíquicos). Pontos: meio

Conjectura psicodinâmica: Sentimentos de menos valia gerando o medo de falhar em sua profissão.

\section{Setor Or:}

S/p: Desconfortos físicos e desmaios por hipoglicemia

Solução: Tenta sem sucesso controlar a glicemia: Solução pouco adequada (soluciona o problema, sem satisfação e sem conflitos).

Conjectura psicodinâmica: A negação maníaca não permite que ela entre em contato com a realidade interna, principalmente com suas condições de saúde, e resolva os conflitos, ocasionando mau controle glicêmico.

\section{Setor S-C:}

Não há s/p neste setor. Não rela nenhum tipo de dificuldade com relação a sociedade. Solução adequada 
Figura 4 - Matriz gráfica do caso Denise

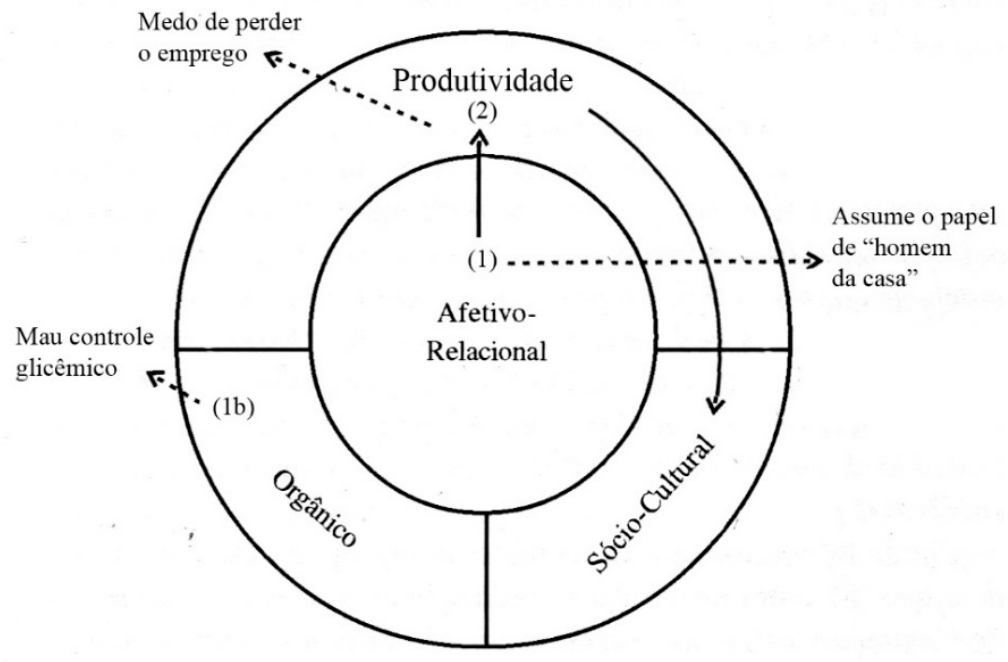

\section{Compreensão psicodinâmica}

Negação muito forte da realidade psíquica. Para lidar com a voracidade ela elimina todo desejo e joga fora (não comer doces na infância). Em relação ao trabalho também: troca arquitetura por pedagogia (curso de menores exigências e status social). Reprime o desejo de evoluir (diz que não aceitaria ser coordenadora ou diretora). Sentir-se estéril, desistir da arquitetura e de evoluir em sua carreira são consequência de sentimentos de menos valia.

Dificuldade tão grande de lidar com as emoções que fica sob a égide das organizações patológicas. Aparentemente feliz, maníaca. Como mecanismo de defesa, usa rigidamente a negação maníaca. Se fecha em copas para proteger ela e o bebê das emoções. Fantasia de proteção.

A culpa pela separação dos pais faz ela assumir o papel de "homem da família", assumindo o papel do pai; e, o medo constante de perder o emprego é decorrência disto. Agora era um momento para se sentir acolhida, sair do papel de "homem da família".

Sente a terapeuta como invasora e, como torna-se mais difícil a negação da realidade interna durante o processo psicoterápico, ela abandona a terapia. Foi tão forte a transferência negativa que não pode dar continuidade a PBO.

\section{Psicoterapia Breve Operacionalizada e sua evolução}

A paciente abandona a PBO após três entrevistas. Por telefone diz que largará a terapia pois está internada e, a terapeuta responde que poderá atende-la na enfermaria, como de 
costume, mas, ela insiste que não, pois necessita ficar quietinha, só ela e o bebê. A terapeuta é vista como intrusa e ameaça o “casulo” que ela própria criou para proteger a si mesma e ao bebê das angústias. Utiliza como principal defesa a negação maníaca.

\subsubsection{Diagnóstico adaptativo, analise dos setores da EDAO e controle glicêmico dos casos}

Tabela 1 - Diagnóstico adaptativo no decorrer do processo psicoterápico

\begin{tabular}{|l|l|l|l|}
\hline Casos & Antes PBO & Após PBO & Follow up \\
\hline Ana & G3 & G3 & G3 \\
Beatriz & G3 & G2, crise postergada & G2 \\
Cecília & G5, em crise & G3 & \\
Denise & G4 & ------------- & -------------- \\
\hline
\end{tabular}

Na tabela 1, das quatro gestantes com DM1 estudadas, duas sofreram mudança no diagnóstico adaptativo, Beatriz e Cecília após a PBO. Denise não realizou a PBO e não houve diagnóstico a ser comparado. Beatriz e Cecília obtiveram melhora e Ana manteve a ineficácia adaptativa adaptativa.

Tabela 2 - Análise dos setores da EDAO antes, depois da PBO e no follow up

\begin{tabular}{|c|c|c|c|c|c|c|c|c|c|c|c|c|c|}
\hline & & $\begin{array}{l}\text { Seto } \\
\text { ante }\end{array}$ & $\begin{array}{l}\text { s d } \\
\text { da } 1\end{array}$ & $\begin{array}{l}\mathrm{DA} \\
\mathrm{O}\end{array}$ & & $\begin{array}{l}\text { Seto } \\
\text { depc }\end{array}$ & $\begin{array}{l}\text { S da } \\
\text { da I }\end{array}$ & $\begin{array}{l}\text { AOO } \\
\text { O }\end{array}$ & & $\begin{array}{l}\text { Seto } \\
\text { follo }\end{array}$ & $\begin{array}{l}\text { s da } \\
\text { up }\end{array}$ & & \\
\hline Casos & $\begin{array}{c}\mathbf{s} / \mathbf{p} \\
\text { nuclear }\end{array}$ & & & & & & $\operatorname{Pr}$ & & SC & $\overline{A R}$ & $\mathrm{Pr}$ & Or & $\overline{S C}$ \\
\hline Ana & AR & A & A & $\mathrm{P}$ & A & A & A & $\mathrm{P}$ & A & A & $\mathrm{pq}$ & $\mathrm{P}$ & $\mathrm{pq}$ \\
\hline Beatriz & AR & $\mathrm{P}$ & $\mathrm{P}$ & $\mathrm{P}$ & $\mathrm{P}$ & A & $\mathrm{P}$ & $\mathrm{P}$ & $\mathrm{P}$ & A & $\mathrm{P}$ & $\mathrm{P}$ & $\mathrm{P}$ \\
\hline Cecília & AR & $\mathrm{pq}$ & pq & $\mathrm{pq}$ & A & $\mathrm{pq}$ & A & $\mathrm{pq}$ & A & --- & ---- & ---- & ---- \\
\hline Denise & AR & $\mathrm{P}$ & $\mathrm{pq}$ & $\mathrm{P}$ & A & --- & ---- & ---- & ---- & --- & ---- & --- & --- \\
\hline
\end{tabular}

A: adequado P: pouco adequado pq: pouquíssimo adequado

Todas as gestantes tiveram s/p no setor Or e, destas, todas com ineficácia adaptativa tiveram a s/p nuclear no setor AR. Na tabela 2, só aparece a crise em Cecília, pois apesar de Beatriz ter entrado em crise adaptativa, ela ocorreu no período posterior a PBO e foi solucionada antes do Follow up. 
Tabela 3 - Porcentagem de medidas de glicemia alteradas nas fases de atendimento

\begin{tabular}{|c|c|c|c|}
\hline Casos & Entrevistas & PBO & Follow up \\
\hline Ana & 59,15 & 69,25 & 59,07 \\
Beatriz & 75,4 & 71,29 & 70,46 \\
\hline
\end{tabular}

Na tabela 3, se evidencia a melhora de porcentagens alteradas em Beatriz e que esta se manteve, já em Ana ocorre uma piora e retorno para o patamar do início das entrevistas. 


\section{DISCUSSÃO}

\subsection{Discussão dos casos}

Ana, Beatriz e Denise sempre vinham acompanhadas de familiares ao pré-natal e isto pode estar relacionado a, desde pequenas, viverem em um ambiente superprotetor, devido aos constantes cuidados que a doença crônica exige. Já Cecília, que desenvolveu o DM1 na vida adulta, sempre foi responsável pela própria saúde e vinha sozinha ao pré-natal.

A ambivalência as levam a não assumirem a responsabilidade por seus atos, e muitas vezes, onipotentemente, simplesmente deixarem na “mão de Deus” ou, acreditarem que não vão engravidar, como Cecília e Denise. Cecília deixava a responsabilidade por conta de seu companheiro (coito interrompido) e Denise, tinha a crença de ser estéril e não era. Cecília, nas três gestações engravidou da mesma forma e sempre com o mesmo comportamento de risco, que se reflete em outros aspectos de sua vida, como colocado nos resultados.

Ana e Beatriz descobriram a gravidez na décima semana de gestação, demonstrando a falta de contato com seu próprio corpo e a negação maníaca, já que existiam sentimentos ambivalente em relação ao feto; Beatriz por estar gravida de outro homem que não seu noivo e Ana por ser gestante, solteira e católica praticante.

Das quatro gestantes, três desenvolveram a DM1 na infância e somente Cecília desenvolveu já na fase adulta. O controle foi avaliado conforme o relato das pacientes e a análise de dextros por computador. Portanto, na infância, adolescência e vida adulta a avaliação se deu conforme a visão sobre si mesmas. Todas relatam o cuidado e bom controle da família na infância e a deterioração do controle glicêmico quando se tornaram responsáveis pela própria saúde. Negam a realidade e assim pensam continuar como na infância, protegidas pelos objetos idealizados. Possuem um padrão de comportamento semelhante: todas iniciam as entrevistas relatando que controlam bem a glicemia na vida adulta, mas, com o decorrer das entrevistas, acabam em algum momento relatando um mau controle glicêmico na vida adulta, o que remete a persecutoriedade vivenciada no período inicial de atendimento. A avaliação do controle glicêmico no período gestacional foi feita com os dados objetivos.

Beatriz é a única dentre as gestantes a sentir culpa por ser corresponsável por seu estado físico, devido a hábitos passados, o que coincide com a afirmação de Santos (2005). Em Ana, Cecília e Denise a ausência da culpa pode ser explicada pelos fatores defensivos utilizados, não há associação entre o mau controle glicêmico - já que fantasiam ter bom controle - e a saúde do bebê, por tanto não há culpa. A autora relata também que há preocupação em manter a gestação, porém as atitudes não condizem com o discurso, assim 
como o encontrado nas gestantes, pois apesar dos medos em relação a saúde do feto, o mau controle glicêmico associado aos maus hábitos se mantém.

Das gestantes atendidas, apenas Beatriz esteve internada durante o atendimento psicológico, por duas vezes (uma durante as entrevistas clínicas e outra após o término da PBO), e, como o relatado pelas enfermeiras da Clínica Obstétrica do HCFMUSP o bom controle glicêmico foi bastante difícil de ser alcançado, e, mesmo com dieta e insulinoterapia rigorosamente controlada, inclusive através da bomba de insulina. A grande porcentagem de valores alterados continuou presente por 15 dias, foram necessários mais 7 dias para permanecer minimamente estável, e, ao sair do hospital, em poucos dias, o controle glicêmico já estava novamente alterado. A angustia pode ser um fator interno psíquico que interfere e agrava condições orgânicas.

Durante a gestação em diabéticas tipo 1 são necessárias sete medições no glicosímetro ao dia e a aplicação de insulina pode ocorrer até seis vezes ao dia - quantidade maior que as diabéticas não gestantes. Além disso, o controle deve ser anotado. É um procedimento complexo, que demanda tempo e atenção contínua. Das gestantes atendidas, somente Cecília queixa da dificuldade e do desconforto deste controle. Quando vai ao restaurante, por exemplo, queixa-se de ter que fazer a medição no banheiro, esperar dez minutos, calcular e aplicar a insulina, enquanto seus acompanhantes esperam à mesa. As outras gestantes não se queixam e relatam tranquilidade no procedimento. Ana, Beatriz e Denise, não fazem o controle glicêmico adequado, desde que se tornaram responsáveis em faze-lo, na adolescência. É possível que isto ocorra pela dificuldade na aceitação da perda do corpo saudável, como verificado por Heleno (2000).

Durante as entrevistas, elas relatam sintomas referentes as crises de hipoglicemia, o que traz grande desconforto na gestação e exacerbam fantasias de morte e má formação fetal. Nem sempre, os relatos das pacientes condizem com a realidade, muitas vezes, elas negam as dificuldades em controlar a glicemia e os maus resultados. Daí surge o comportamento dos médicos - que "assumem o papel dos pais” das gestantes - em conferir a tabela de controle preenchida pelas gestantes com a memória do aparelho. Segundo os relatos médicos, é comum elas se “enganarem” nas anotações, principalmente naquelas com grande alteração. Mesmo cientes de que o médico irá conferir, continuam se "enganando”, sempre para um resultado mais próximo do controle satisfatório. Podemos conjecturar que, inconscientemente em cotransferência, queiram a atenção e os cuidados dos médicos, que "assumem” o papel de pais. 
Por intermédio do acompanhamento da evolução do controle glicêmico, pode-se perceber alterações neste controle nas diferentes fases do atendimento: entrevistas, PBO e follow up. Não foi possível associar às interpretações teorizadas. A porcentagem de hipoglicemias e hipoglicemias graves melhoraram com o decorrer da PBO, o que reflete na qualidade de vida da gestante, já que os desmaios decorrentes causam transtornos e desconfortos físicos e exacerbam o medo de morte do bebê. Segundo os profissionais da saúde da Clínica Obstétrica do HCFMUSP, a hipoglicemia é mais facilmente controlada pelas gestantes, se seguirem a prescrição medica e dietas nutricionais.

Entretanto, a porcentagem de valores alterados e de hiperglicemias tiveram piora durante o processo psicoterapêutico. Com o desenvolvimento da gravidez há uma tendência ao aumento das hiperglicemias, mesmo com o rigoroso controle alimentar e insulinoterapia, inclusive em internações, as hiperglicemias foram mais dificilmente controladas e parecem estar mais sujeitas à alteração com o estresse emocional. Beatriz descreve sua emoção durante o parto e como ocorreu a hiperglicemia em decorrência:

Paciente: - “Nossa...quando ele nasceu, no parto eu estava desesperada para ver o rosto dele...”

Terapeuta: - "Para saber a aparência física?”

Paciente: - "Para saber se ele era parecido com meu ex namorado ou comigo.... Eu estava tão nervosa.... Senti medo dele ser a cara do meu ex namorado. Quando eles me mostraram o bebê e eu vi que ele era parecido comigo eu desmaiei... comecei a chorar e tremer e amoleci, apaguei de nervoso, sei lá. A minha glicemia foi para as alturas, eles controlaram e me deram remédio para dormir. Acordei no quarto. Soube que a minha glicemia subiu...”

O medo do bebê nascer doente ou anômalo, surgem em Beatriz e Cecília, com grande intensidade e, parecem ser acentuados devido ao risco real. Contudo, Beatriz, devido a culpa pela gravidez, segue atormentada por estes medos, apesar da confirmação médica da boa formação e saúde do bebê, como descrito em diversos estudos (Quevedo et al., 2006; P. B. Santos, 2005; Tedesco, 1997). Em Beatriz, através das interpretações teorizadas e técnicas suportivas estes medos foram minimizados. Conforme Tedesco (1997), o medo de ter uma criança anômala salienta a perda do controle sobre seu próprio corpo e gravidez, podendo gerar um aumento da ansiedade e, Beatriz e Cecília apresentam esta correlação. Já Ana e Denise, ambas com utilização da defesa negação de forma intensa, não demonstraram ansiedade. 
Ana recusa desde a infância a desenvolver-se, mantendo-se dependente da mãe e infantilizada. Cecília age como uma menina, buscando a avó paterna na cotransferência com sua sogra para conseguir controle e organização, mas não há identificação com o feto e nem investimento libidinal nele. Beatriz também apresenta um funcionamento psíquico infantil e, assim como Denise, utiliza defesas do ego imaturas, principalmente negação maníaca. Apresentam solução mágica para seus problemas. Podemos perceber que todas as gestantes estudadas se mostram infantilizadas concordante com Wutke (2009), porém, inversamente ao descrito por Ferreira (2009), não há retorno a fases anteriores e sim uma permanência no estado infantil, que impedem o total desenvolvimento adulto.

Em relação a necessidade de proteção e cuidado, de modo diverso ao exposto por Ferreira (2009), Ana demonstra esta necessidade desde muito pequena e tenta manter os cuidados maternos, por outro lado, há dificuldade em suportar a dependência, inclusive da terapeuta. Denise se auto denomina o "homem da casa”, provedor e atuante, e inversamente não relata esta necessidade. Esta questão faria parte da interpretação teorizada, caso a paciente tivesse dado continuidade a PBO, visto que, este é o momento de sentir-se acolhida. Cecília, assim como as gestantes do estudo de Ferreira (2009), relata constantemente o desejo de estabilidade e proteção e Beatriz, retrata o noivo com muitas qualidades, sendo uma delas a capacidade de cuidado e proteção que oferece.

Na presente pesquisa, assim como nas gestantes investigadas por Ferreira (2009), aparece o desejo de não entrar em contato com sentimentos negativos que provocam angústia. Ana, Beatriz e Denise, da mesma forma, apresentam constantemente o mecanismo de defesa negação. A negação e o instinto de morte preponderante, com tendências autodestrutivas, parece estar presente também em outros estudos (Costa, 2002; Heleno, 2000).

No presente estudo, no caso de Denise e Ana, assim como na pesquisa de Heleno (2000), as organizações patológicas (Steiner, 1997), impediram o tratamento e a melhora na qualidade de vida. Todavia, Beatriz pôde realizar todo o tratamento e se beneficiar da técnica e Cecília, apesar de interrupção prematura devido o aborto também se beneficiou. Contudo, foi a negação maníaca que surgiu como impedimento para o contato com o mundo interno.

Ana e Denise, assim como descrito por Steiner (1997), sentiram a terapeuta como uma intrusa, que ameaçava a aparente tranquilidade. Elas evitam, a qualquer custo, entrar em contato com as angústias, através da negação maníaca maciça. A forte transferência negativa que ocorreu nos dois casos surge, principalmente, pelo fato das pacientes, tentarem não entrar em contato com a realidade interna, que a psicoterapia propicia. 
Em relação ao atendimento psicológico acontece o mesmo ao descrito por Szejer \& Stewart (1997), quando há dificuldade na confrontação com a realidade externa e interna, a psicóloga foi sentida como invasiva e amedrontadora; e com Denise e Beatriz o encontro possibilitou a expressão das angústias.

Ana e Denise parecem sentir como compulsória a participação na pesquisa, devido o encaminhamento médico e, por tanto, o interesse relatado - durante a apresentação da pesquisa - em fazer a $\mathrm{PBO}$, seria não genuíno. A falta de motivação para a terapia, pode prejudicar o andamento da PBO e seus resultados. É possível que Ana e Denise estivessem no estágio de pré-contemplação (Prochaska, 1995), pois relatam de forma pouco constante o controle glicêmico, não parecem ter uma consciência clara de seu controle glicêmico e não demonstram interesse em receber ajuda. Desta forma seriam menos propícias às mudanças. Contudo, como percebemos nos resultados, mesmo sem muita motivação, Ana pode, de forma mais restrita, se beneficiar da técnica. Já a Cecília, que sempre teve maior interesse na terapia, relatava a necessidade de ajuda e via a terapia como uma oportunidade em melhorar, possivelmente se beneficiaria mais, ou pelo menos, estaria mais propensa a mudança. Além da consciência de seu problema, ela queria a ajuda para resolver seus problemas emocionais.

Em estudo realizado em uma clínica-escola demonstra que quando há uma boa aliança terapêutica, atingir bons resultados com os pacientes é mais fácil, se eles se encontrarem em um estágio propício a mudança psicológica (Honda \& Yoshida, 2012). Uma boa aliança terapêutica não foi alcançada com Ana, Beatriz e Denise, visto a falta de motivação e a transferência negativa. Com Beatriz, através da interpretação da transferência negativa, foi possível minimiza-la, e dar continuidade a terapia, beneficiando assim a paciente. Já com Ana e Denise, a transferência negativa foi preponderante, e, mesmo com interpretações, a resistência das pacientes não permitiu diluí-las. As organizações patológicas trabalham como uma barreira, para manter as pacientes afastadas das angustias e a terapeuta parece ser sentida como uma ameaça a esta "proteção” patológica. Denise usa como argumento para interrupção da terapia que “é um momento que eu preciso ficar quietinha, só eu e meu bebê”, denunciando a "intrusão" da terapeuta.

Se pensarmos no funcionamento psicodinâmico destas pacientes, pode-se perceber um padrão de funcionamento. Todas as 4 gestantes tinham mau controle glicêmico prévio e revelaram preponderância do instinto de morte, o que confere com o descrito por Simon (2005).

Beatriz, assim como descrito por Rapoport e Piccinini (2011), quer ser mãe ideal, não se permitindo expressar os sentimentos ambivalentes existentes. Ana e Denise não 
apresentam, em nenhum momento, sentimentos ambivalentes em relação a gestação. Já Cecília é tomada pela dúvida, inconsciente, em manter a gravidez ou seguir com ela; e acaba por abortar espontaneamente, evidenciando a decisão proposta por Camacho et al (2010).

O que chama mais atenção no caso de Ana é o fato do diagnóstico antes e depois da PBO ter sido G1 - adaptação eficaz - e, no follow up, ter sido confirmado o diagnostico no G3 - adaptação ineficaz moderada. Isto se deve não a queda, de fato, da eficácia da adaptação, mas sim, às informações que foram escondidas e que seriam necessárias ao diagnóstico correto. A insistência da paciente em não dividir com a terapeuta as dificuldades enfrentadas em sua vida, se deve, principalmente, a dificuldade em confiar na terapeuta - Ana tem seus vínculos permeados de persecutoriedade.

Contudo, não se pode diagnosticar baseando-se em hipóteses. O material deve ser encontrado nas entrevistas, na história pregressa e nos fatores que, objetivamente, a paciente não trazia (Simon, 2005). Antes da PBO sua adaptação condizia com um diagnóstico de G1 e, no follow up com o G3. Os achados obtidos por Heleno (2000), apesar de serem referentes a pacientes portadores de DM2 e não gestantes com DM1, reforçam esta hipótese: pacientes diabético com mau controle glicêmico pertencem aos G4 e G5 principalmente, e poucos ao G3, ou seja, ela não poderia ser G1 e ter mau controle glicêmico.

A paciente poderia ser diagnosticada por G3, adaptação Ineficaz moderada, com tendência a queda no setor AR e Pr. A queda em Pr pode acorrer caso ela perca o processo e tenha que fazer a devolução do dinheiro recebido indevidamente. Segundo Simon (2011), o nascimento do primeiro filho, equivale a uma grande redução do espaço do universo pessoal da gestante, o que aumenta, em muito, a possibilidade de Ana vivenciar uma crise adaptativa.

Podemos conjecturar que, com o nascimento do bebê, a paciente pode identifica-lo com o irmão mais novo, revivendo o momento do desmame e desenvolvimento do diabetes. Da mesma forma que fez com o irmão a paciente entrará em competição com o próprio filho pela atenção recebida de todos. Deixará de ser o foco e estar no centro. Segundo Ana, ela “venceu a competição” através do diabetes. Continuou a ser tratada como a eterna caçula da casa. E agora? Como agirá para manter esta posição? Não podemos prever.

Durante a PBO, algo estava fazendo com que Ana criasse um mundo próprio, de fantasias, onde tudo era mágico e perfeito. Sem conflitos e angústias. Tudo estava bem: "Está tudo bem! Meu relacionamento é ótimo, nos amamos, vamos nos casar, ele virá morar comigo e construir uma casa ... está tudo bem! ”. É uma zona de conforto no meio do desconforto. Um bolsão de ar. Com essas defesas ela mantém aparentemente a eficácia da adaptação. Ela vive sua alegria baseada no futuro perfeito que, conforme seus planos, um dia chegará. 
Estas são características de pacientes que entram em “refúgios psíquicos” para se proteger da realidade ou do terapeuta sentidos como ameaçadores (Steiner, 1997). Para Ana, a terapeuta representava a possibilidade de entrar em contato com as angustias, mas como ela estava "refugiada”, a terapeuta acabava sendo sentida como uma ameaça. O distanciamento, neste caso, se realiza através de superioridade, arrogância e controle onipotente: um falso contato (superficial e desonesto). Ela demonstra a falta de contato com seu mundo interno e, inclusive, descobriu a gravidez na décima semana de gestação.

O distanciamento de Ana se dá através da negação dos sentimentos, expressando estar sempre bem, negando as emoções que pudessem levar as angustias, inclusive o mau controle glicêmico. A paciente mostra-se como uma rainha infantil: A “ditadura da criancinha”. O que Ana relata como relação contraditória com a família, não é contradição, é uma reação defensiva, a negação da dependência.

O trecho a seguir, demonstra a tentativa de esconder de si e dos outros as dificuldades que a paciente enfrenta, e, como, após a confrontação com a realidade, a paciente muda o discurso:

Terapeuta: - “Ao meu ver você se mostra bem adaptada, as coisas estão saindo sem nenhum problema aparente, a gravidez está bem, o bebê está se desenvolvendo bem. O seu relacionamento é ótimo. Com o trabalho você também está satisfeita. Mas apesar de você relatar que seu controle glicêmico está bom, vi nos registros que há alterações nos seus dextros. Há 3\% de hipoglicemias graves e 50\% de valores alterados, o que me parece preocupante. ”

Paciente: - “Ah sim! Está bom, mas os médicos dizem que há muito o que melhorar. Tem um pouco de descontrole, principalmente porque tenho ido diariamente a médicos e exames e por ser de outra cidade acaba alterando o horário da refeição e comer lanche não é igual a comer almoço. Mas está razoavelmente bem. Tenho uma conhecida que chegou a 800 na gestação e o bebê nasceu super bem”

Terapeuta: - "Me parece que você não quer se abrir, quer guardar para você mesma. Esse é a sua vontade? Esconder as dificuldades? Eu não vou dizer o que você me contar para te prejudicar. Estou aqui para te ajudar. Mas, o que você resolver eu respeito. ”

Paciente: - "Mas está tudo bem... Meu relacionamento, minha gravidez, minha saúde e a do bebê. Vamos nos casar, construir uma casa ... está tudo bem. ”

É possível que esta paciente consiga manter-se afastada destas angustias como numa cegueira proposital? 
Pode ser identificado no histórico de Ana todos os nove micro-fatores identificados por Heleno (2000): não é capaz de aceitar a perda do corpo saudável; não suporta a dependência; dificuldade para discriminar a qualidade dos objetos; os vínculos estabelecidos são permeados pela persecutoriedade; os objetos são sentidos com cruéis e perversos; apresenta sentimentos de onipotência e arrogância; não é capaz de utilizar a capacidade produtiva; incapacidade de utilizar a agressividade de forma construtiva, e; ganhos secundários com a doença.

Todo o processo de PBO foi permeado pela transferência negativa, como podemos perceber na transcrição a seguir:

Terapeuta: - “Tenho a impressão de que você não se sente muito motivada para a terapia, você prefere ficar em silêncio? ”

Paciente: - "Não, eu gosto, me sinto motivada. ”

Terapeuta: - "Se você se sente motivada, mas mesmo assim prefere não se abrir comigo, talvez possa ser porque você tem dificuldade de confiar em mim, por medo de se machucar. ” Paciente: - "Não! Me sinto tranquila, me sinto bem. ”

Neste momento a paciente tenta fugir do assunto introduzindo questões corriqueiras do cotidiano. A terapeuta escuta a paciente e tenta trazê-la de volta ao assunto:

Terapeuta: - "Semana passada quando conversamos, você me falou sobre o medo de injeção e que quando você se aplica você não tem medo. O medo vem dos outros te machucarem ou não serem confiáveis? ”

Paciente: - "Não estou tranquila em relação a isso... Mas na injeção sim, medo de doer quando outra pessoa aplica. Mas consigo confiar nas pessoas. ”

A Paciente sente-se perseguida. Há a fantasia que o outro vai tratá-la sadicamente. Segundo Simon (2005), a transferência negativa deve ser interpretada desde o início das entrevistas, pois ela impede que a psicoterapia se desenvolva, prejudicando o tratamento. Neste caso, a interpretação da transferência negativa foi prejudicada pela negação das interpretações e pela falta de material trazido para a psicoterapia, impedindo o aprofundamento e a compreensão psicanalítica. A falta de material funcionou como uma barreira que dificultou a formulação das interpretações teorizadas necessárias para dissolver ou minimizar a transferência negativa.

Quanto mais a terapeuta oferecia ajuda, mais se tornava uma figura ameaçadora, sentida por Ana como uma intrusa e mais Ana negava qualquer interpretação e se fechava para a psicoterapia. Na tentativa de mostrar a realidade para a paciente, para que pudessem ser feitas e aceitas interpretações, a terapeuta, transferencialmente, tornou-se superegóica. Com a 
hipótese de que houvesse algum conflito psíquico no fato da paciente ser catequista e estar gerando um bebê antes do casamento a psicóloga pergunta:

Terapeuta: - "E você pretendem casar na igreja? ”

Paciente: - "Sim!

Terapeuta: - "Mas e o padre, ele permite. Como ele te tratou quando soube da gravidez? ”

Paciente: - "Sim. Ele me parabenizou (fala rindo), mais nada."

Terapeuta: - “Este padre é moderninho então!?”

Paciente: - “É. Lógico que eles falam de sexo só depois do casamento. Mas já era esperada esta gravidez...”

A arrogância e superioridade de Ana estiveram presente desde o primeiro encontro na triagem, favorecendo a contratransferência negativa: Quando foi oferecida a leitura do TCLE, procedimento corriqueiro, ela mostrou-se ofendida: “Já estou no fim da faculdade, não preciso que ninguém leia nada para mim! ”.

Apesar das dificuldades enfrentadas na PBO pode-se perceber que ocorreram modificações no controle glicêmico, principalmente durante as sessões de PBO. Com o início das entrevistas houve uma queda considerável na porcentagem de hipoglicemias graves. Se forem considerados os desconfortos psíquicos que trazem este estado orgânico e o quanto são sentidos como perigosos para a gestante, pode-se dizer que é um grande avanço em direção a qualidade de vida. Ana descreve como possivelmente letais e preocupantes devido aos desmaios decorrentes, possível coma e morte. Também os valores de hipoglicemias menos graves diminuíram com o início da PBO.

Apesar de Ana se mostrar tão resistente e refratária, o fato da terapeuta ter aguentado os ataques, ter acolhido e ter cuidado, com preocupação e interesse, ocasionou melhora na hipoglicemia, demonstrando que a terapia, possivelmente, funciou como fator externo positivo.

A porcentagem valores alterados, ou seja, fora dos valores desejáveis, ficou mais alta a partir do início das sessões e a porcentagem de hiperglicemias também sofreu piora. O período entre o fim dos atendimentos e a entrevista de follow up é marcado pelo retorno dos valores para o patamar anterior. Podemos conjecturar que Ana por ter muitos conflitos internos, para se manter refratária precisa de um grande esforço psíquico (inconsciente) e uma alto custo. Sem a PBO ela volta ao estado normal de negação, arrogância e afastamento da realidade psíquica, ou, é possível que, com a proximidade do parto, ela não tenha conseguido manter os ganhos. 
No caso Beatriz, no primeiro diagnóstico a paciente foi classificada no G3, adaptação Ineficaz moderada. Beatriz tem preponderância do instinto de morte, utiliza-se de defesas infantis, que trazem prejuízos a sua vida. Engravidou, mesmo com o relacionamento decadente, possivelmente, na esperança de salvar a relação. Podemos perceber atuante também seu instinto de vida. O fato dela optar pelo noivo, que traz estabilidade emocional e que se mostra um futuro bom pai, amoroso e provedor, demostra isso. O noivo atua como fator externo positivo, contribuindo para um ambiente acolhedor.

Pode-se perceber que Beatriz é dependente do ambiente para manter a eficácia da adaptação, e, o noivo, teve importância central nisto. Analisando mais profundamente seus fatores, vemos que, segundo Simon (2005), ela seria uma paciente com tendência a encontrar soluções pouquíssimo adequadas. A terapia também funciona como fator externo positivo; e, ela se sentir compreendida, poder conversar com alguém sobre a imensa culpa que sentia; e, fazer uma escolha consciente, possibilitou melhorar mais ainda a eficácia da adaptação. Esta é uma paciente que teria dificuldade em evoluir mais a eficácia da adaptação, além do avanço alcançado, pois através da PBO, alteramos o ambiente, mas, a constituição do indivíduo é dificilmente alterada.

Outra questão interessante, é que Beatriz vivenciou a crise, nos dias que antecederam o parto, e não, com o nascimento do bebê como o esperado (Simon, 2005). Geralmente, o nascimento do primeiro filho é um acontecimento potencialmente gerador de crise. As fantasias e o medo de que o bebê nascesse idêntico ao pai biológico, denunciando o erro cometido, geraram crise por expectativa de perda, e assim, com o nascimento do bebê e a percepção de que o bebê parecia com ela própria, e, ao contrário de sua fantasia, não revelava o segredo, o nascimento foi uma situação que trouxe alívio e solução da crise, sem queda na eficácia adaptativa.

Younes, (2011); Younes, Lessa, Yamamoto, Coniaric e Ditzz (2010) e Simon e Yamamoto (2008) demonstraram que através da PBO é possível auxiliar os pacientes a lidarem com a crise adaptativa na qual se encontravam, sem prejuízos para o nível adaptativo. Beatriz, vivenciou a crise após o término das sessões, antes do follow up, mas o crescimento alcançado durante a PBO e a diminuição dos conflitos, foram fundamentais para que ela fosse capaz de solucionar a crise sozinha, sem prejuízos para a eficácia adaptativa.

Pode-se perceber mudanças no controle glicêmico conforme as fases do atendimento em PBO. A porcentagem de valores alterados teve declínio demonstrando a melhora no controle. A hiperglicemia teve um aumento constante, apesar das internações (com controle rígido) o que demonstra que as angustias e conflitos não desapareceram, apesar de 
aparentemente terem sido minimizados. No relato obtido no follow up, Beatriz nos mostra como sua hiperglicemia disparou no momento do parto, pelo medo que o bebê tivesse alguma semelhança física com o pai biológico. A angustia foi tamanha que a paciente desmaiou, o que fortalece a discussão da hiperglicemia poder estar relacionada a estresse e alterações emocionais. Pode-se conjecturar que quanto mais próximo o parto, mais alto os valores de hiperglicemias, alcançando seu auge no momento do parto, devido as angustias relacionada aos medos de morte e doença do bebê e, como relatado pela paciente, medo que seu erro ficasse visível a todos, sendo exposto seu pecado.

As porcentagens de hipoglicemias e hipoglicemias graves tiveram um declínio significativo e puderam ser mantidas, demonstrando benefícios nestes valores. Elas podem estar mais relacionadas ao controle em si, tendo menos influência das emoções. Se considerarmos que, com a gestação, o número de hipoglicemias tende a aumentar, sendo este desconforto relatado pela paciente, pode ser considerado um avanço em direção à saúde e a qualidade de vida desta paciente.

Cecília não foi um caso que chegou a termo, devido ao aborto espontâneo e o consequente desligamento da paciente do pré-natal de risco, mas, é importante notar que, a PBO teve importância central na modificação do diagnóstico adaptativo. A paciente se encontrava em crise e com diagnóstico G5 - adaptação ineficaz Grave.

Cecília estava passando por um momento delicado, no qual acabava de conquistar uma pseudo estabilidade, devido ao emprego conquistado pelo marido ex dependente químico. Há poucos meses mudou-se da casa da sogra e finalmente (após três anos) tinha novamente sua própria casa. Seus planos no setor $\mathrm{Pr}$, condiziam com a realidade e se seguisse o planejamento, possivelmente conseguiria conquistar a sonhada independência financeira. A gravidez, neste momento, prejudicaria seus planos a curto e longo prazo.

Ao participar das entrevistas clínicas, ela pode sentir-se acolhida e sem julgamento, o que possibilitou ela entrar em contato com seus sentimentos ambíguos em relação ao feto e a gestação. Era uma gravidez desejada por seus familiares e, a paciente, queria mantê-la para satisfazer os desejos do marido e do filho. Já não havia investimento libidinal no feto, e, ela se permitiu (inconscientemente) abortar espontaneamente, o que trouxe alívio a paciente. $\mathrm{O}$ abortamento, neste caso, funcionou como fator externo positivo.

Existiam outras s/p a serem trabalhadas, principalmente no setor A-R, que, por ser uma s/p nuclear (colocar-se constantemente em situações de risco e auto sabotagem) ocasionou a gravidez não planejada. Possivelmente ela continuará a encontrar soluções pouco e pouquíssimo adequadas para suas s/p, mas, ela conseguiu, neste momento, encontrar uma 
solução adequada para a crise que estava vivendo, e teve, com isso, uma melhora substancial em seu diagnóstico adaptativo.

\section{CONCLUSÃO}

Em relação ao psicodinamismo, observa-se que, em comum, as gestantes da pesquisa possuem funcionamento psíquico característico da fase esquizo paranoide, utilizando como principal defesa do ego a negação maníaca. O pensamento mágico se mostra presente e possuem instinto de morte preponderante e, consequente persecutoriedade. As gestantes estudadas possuem tendência a encontrar soluções pouco e pouquíssimo adequadas devido ao seu psicodinamismo.

Comparando o diagnóstico adaptativo das gestantes com ineficácia adaptativa, antes e após a PBO, pode-se constatar, que houve mudanças de grupo adaptativo da qual pertenciam, como se verificou em Cecília e Beatriz. Cecília não fez follow up, apenas Beatriz o realizou, e nele demonstrou ter mantido a melhora na eficácia da adaptação.

Por intermédio do acompanhamento da evolução do controle glicêmico, pode-se verificar nas gestantes, alterações neste controle com o decorrer da PBO. A porcentagem de hipoglicemias e hipoglicemias graves melhoraram. A porcentagem de valores alterados e de hiperglicemias, por sua vez, tiveram piora com o decorrer do da gravidez e mesmo com a PBO, o rigoroso controle alimentar e insulinoterapia, inclusive em internações, foram dificilmente controlados.

Das quatro gestantes estudadas duas tiveram crise adaptativa e as soluções encontradas por elas foram satisfatórias. Foi perceptível que a PBO ajudou estas gestantes a conseguirem encontrar soluções mais eficazes e mesmo em crise, conseguiram manter a eficácia da adaptação, sem queda de grupo adaptativo.

O que pode restringir o processo psicoterapêutico foi a transferência negativa 
persistente. Quando prepondera com grande intensidade ela pode impossibilitar a continuidade da PBO, como no caso de Denise que preferiu abandonar a pesquisa. Em Ana, bloqueou qualquer o progresso da terapia, e, apesar da continuidade da PBO, prejudicou o diagnóstico, a formulação de interpretações teorizadas e impossibilitou resultados positivos. Contudo, Beatriz, mesmo com transferência negativa, pode se beneficiar da técnica, após sua interpretação imediata e consequente diminuição da transferência negativa. Então, a transferência negativa pode, às vezes, ser um limite para a PBO, mas pode também ser trabalhada e minimizada - uma barreira transponível.

Com os casos Beatriz e Cecília, foi possível averiguar algumas possibilidades da PBO no atendimento às gestantes com DM1: foi uma técnica útil e eficiente para a melhoria da eficácia da adaptação; auxiliou Beatriz e Cecília a solucionarem a crise adaptativa sem que houvesse queda da eficácia da adaptação; e, possibilitou as pacientes a encontrarem soluções mais adequadas para suas situações-problema.

Devido ao número limitado da amostra, não é possível generalizar os resultados para outras gestantes com DM1, mas, este estudo indica uma direção: a possibilidade do uso da PBO, como uma ferramenta útil ao psicólogo, para auxiliar as gestantes com DM1 e mau controle glicêmico. Para tanto, é necessário que o psicólogo de uma atenção especial a transferência negativa, que devido a persecutoriedade destas pacientes surge de modo exacerbado e, desde o primeiro contato com a paciente ela pode ser trabalhada e minimizada através de sua interpretação imediata. São necessárias pesquisas com uma amostra maior para desenvolver uma abordagem e atendimento adequado às gestantes com DM1 e mau controle glicêmico. 


\section{REFERÊNCIAS}

Barbosa, R. F., Duarte, C. A. M., \& Santos, L. P. d. (2012). Psicossomática, Gestação e Diabetes:Um Estudo de Caso Psicologia: Ciência Profissão, 32(2), 472483.Recuperado em 20 de julho de 2014 http://www.scielo.br/scielo. php? Pid =S1414-98932012000200014\&script=sci_arttext

Bechara, G. M. (2011). Diabetes Mellitus tipo 1: Evolução da eficácia adaptativa e psicoterapia breve operacionalizada. Dissertação de Mestrado, Universidade Metodista de São Paulo, São Bernardo do Campo.

Bellack, L., \& Small, L. (1980). Psicoterapia de emergência e psicoterapia breve. Porto Alegre Artes Médicas.

Bomfim, T. E. (2010). Saúde mental e sofrimento psíquico de indígena Guarani-Mbyá de São Paulo: Um relato de experiência. Tese de Doutorado, Universidade de São Paulo, São Paulo.

Camacho, K. G., Vargens, O. M. d. C., Progianti, J. M., \& Spíndola, T. (2010). Vivenciando repercurssões e transformações de uma gestação: perspectivas de gestantes. Ciencia y enfermería, 16, 115-125.

Coniaric, J. (2011 ). Diagnóstico adaptativo familiar:Um estudo piloto. Dissertação de Mestrado, Universidade de São Paulo, São Paulo. 
Cordero, L., Treuer, S. H., Landon, M. B., \& Gabbe, S. G. (1998). Management of infants of diabetic mothers Arch Pediatr Adolesc Med, 152(3), 249-254.

Corrêa, F. H. S., \& Gomes, M. d. B. (2004). Acompanhamento ambulatorial de gestantes com diabetes mellitus no Hospital Universitário Pedro Ernesto - UERJ. Arquivos Brasileiros de Endocrinologia \& Metabologia, 48, 499-504.

Costa, E. H. A. (2002). O uso do desenho da Figura Humana e da Figura Humana com tema na investigação psicológica do paciente com diabetes em grupo psicoeducativo no contexto hospitalar. Psic: revista da Vetor Editora, 3(1), 28-57. Recuperado em 20 de julho de 2014 <http://pepsic.bvsalud. org/scielo. php?script=sci_arttext\&pid=S1676$73142002000100004 \& \operatorname{lng}=p t \& n r m=i s o>$. ISSN 1676-7314.

Sociedade Brasileira de Diabetes(2009). Diretrizes da sociedade brasileira de diabetes 2009 Recuperado em 15 de agosto de 2014 http://www.diabetes.org.br/ attachments/diretrizes09_final.pdf

Eidem, I., Stene, L. C., Henriksen, T., Hanssen, K. F., Vangen, S., Vollset, S. E., \& Joner, G. (2010). Congenital anomalies in newborns of women with type 1 diabetes: nationwide population-based study in Norway, 1999-2004. Acta Obstetricia et Gynecologica Scandinavica, 89(11), 1403-1411.

Ferreira, A. C. F. (2009). Psicodinamismos de grávidas com gestação de alto risco por Diabetes Mellitus pré-gestacional. Dissertação de Mestrado, Faculdade de Filosofia, Ciências e Letras de Ribeirão Preto, Ribeirão Preto. Recuperado em 28 de outubro de 2013 http://www.ffclrp.usp.br/imagens_defesas/20_05_2010__11_03_47_43.pdf

Fiorini, H. T. (1993). Teoria e técnica de psicoterapia. São Paulo: EPU.

Freud, S. (1996). Sobre o início do tratamento (Novas recomendações sobre a técnica da psicanálise I)(1913). Edição Standard Brasileira das Obras Psicológicas Completas de Sigmund Freud, 164-187.

Gebara, A. C. (2009). Pesquisa sobre a eficácia terapêutica da interpretação teorizada na psicoterapia breve operacionalizada. São Paulo.

Gebara, A. C., Rosa, J. T., Simon, R., \& Yamamoto, K. (2004). Eficácia terapêutica da Interpretação Teorizada na Psicoterapia Breve. 5(1), 6-15. Recuperado em30 de julho de $2014<$ http://pepsic.bvsalud.org/scielo.php?pid=S1676$\underline{73142004000100002 \& \text { script }=\text { sci_arttext }>\text {. }}$ 
Golbert, A., \& Campos, M. A. A. (2008). Diabetes Melito Tipo 1 e Gestação. Arquivos Brasileiros de Endrocrinologia Metabologia, 52(2), 307-314. Recuperado em 10 de maio de 2014 http://www.scielo.br/pdf/abem/v52n2/18.pdf

Control and Complications Trial Research Group (2000). Effect of pregnancy on microvascular complications in the diabetes control and complications trial. Diabetes Care, 8, 84-91.

Hayden, T., Perantie, D. C., Nix, B. D., Barnes, L. D., Mostello, D. J., Holcomb, W. L., . . Hershey, T. (2012). Treating Prepartum Depression to Improve Infant DevelopmentalOutcomes: A Study of Diabetes in Pregnancy. J Clin Psychol Med Settings, (19), 285-292.

Heleno, M. G. V. (2000). Organizações patológicas e equilíbrio psíquico em pacientes diabéticos tipo 2. Tese de Doutorado, Universidade de São Paulo, São Paulo.

Honda, G. C., \& Yoshida, E. M. P. (2012). Mudança em pacientes de clínica-escola: avaliação de resultados e processos. Paidéia, 22(51), 73-82.

Jovanovic, L. (2004). Glucose and insulin requirements during labor anddelivery: the case for normoglycemia in pregnancies complicatedby diabetes. Endocr Pract, 10(Suplemento), 40-45.

Klein, M. (1937). Amor, culpa e reparação Amor, culpa e reparação e outros trabalhos (1921-1945) (pp. 346-384). Rio de Janeiro: Imago.

Knobel, M. (1986). Psicoterapia breve. São Paulo: EPU.

Leavell, H. R., \& Clark, E. G. (1965). Preventive medicine for the doctor in his community: an epidemiological approach. (3ed. ed.). New York: MacGraw-Hill.

Maia, F. F. R., \& Araújo, L. R. (2004). Aspectos Psicológicos e Controle Glicêmico de Um Grupo de Pacientes Com Diabetes Mellitus Tipo 1 em Minas Gerais. Arquivos Brasileiros de Endocrinologia e Metabologia, 48(2), 261-266. Recuperado em 20 de julho de 2014 em http://www.scielo.br/pdf/abem/ v48n2/ a09v 48n2.pdf

Malan, D. (1981). As fronteiras da psicoterapia breve. Porto Alegre: Artes Médicas.

Maldonado, M. T. (2002). Psicologia da Gravidez: parto e puerpério. São Paulo: Saraiva. 
Manderson, J. G., Patterson, C. C., Hadden, D. R., Traub, A. I., Ennis, C., \& McCance, D. R. (2003). Preprandial versus postprandial blood glucose monitoring in type 1 diabetic pregnancy: a randomized controlled clinical trial. Am J Obstet Gynecol, 189(2), 507512.

Menezes, C. C., \& Lopes, R. C. S. (2007). Relação conjugal na transiçao para a parentalidade: gestaçao até os dezoito meses do bebê. . Psico - USF, 12(1), 83-93. Recuperado em 20 de julho de 2014 http://www.scielo.br/pdf/pusf/v12n1/ v12n1a10.pdf

Montenegro Jr, R. M., Paccola, G. M. F. G., Faria, C. M., Sales, A. P. M., Montenegro, A. P. D. R., Jorge, S. M., . . Foss, M. C. (2001). Evolução materno-fetal de gestantes diabéticas seguidas no HC-FMRP-USP no período de 1992-1999. Arquivos Brasileiros de Endocrinologia \& Metabologia, 45, 467-474.

Neder, C. R., \& Simon, R. (2004). Diagnóstico da adaptação, teste estilocromico e psicoterapia breve operacionalizada em transplante de fígado. Mudanças, 12, 7-93.

Nold, J. L., \& Georgieff, M. K. (2004). Infants of diabetic mothers. Pediatric Clinics of North America, 51(3), 619-637. Recuperado em 20 de julho de 2014 http://dx. doi.org/10.1016/j.pcl.2004.01.003

Prochaska, J. O. (1995). An eclectic and integrative approach: Transtheoretical therapy.

Quevedo, M. P., Lopes, C. M. C., \& Lefèvre, F. (2006). Os significados da maternidade para mulheres cardiopatas e diabéticas com gravidez de risco; The meanings of maternity to high-risk pregnant women with valvar heart disease and diabetes. Journal of Human Growth and Development, 16(1), 12-21.

Rapoport, A., \& Piccinini, C. A. (2011). Maternidade e situações estressantes no primeiro ano de vida do bebê. Psico-USF., 16(2), 215-225.Recuperado em 15 de junho de 2014 http://dx.doi.org/10.1590/S1413-82712011000200010.

Ray, J. G., O'Brien, T. E., \& Chan, W. S. (2001). Preconception care and the risk of congenital anomalies in the offspring of women with diabetes mellitus: a metaanalysis. Kansas Journal of Medicine, 94, 435-444.

Santana, M. A. (2010). Qualidade de vida e eficácia adaptativa de pessoas com obesidade. Dissertação de mestrado, Universidade Metodista de São Paulo, São Bernardo do Camopo. 
Santos, M. C. d., Honda, G. C., Santeiro, T. V., \& Yoshida, E. M. P. (2013). Eficácia adaptativa: produção científica brasileira (2002/2012). Contextos Clínicos, 6(2), 8494.

Santos, P. B. (2005). Maternidade ameaçada: vivências psíquicas em gestantes de risco. (Mestrado), Pontífera Universidade Católica, São Paulo.

Portaria n. 2.583 de 10 de outubro, (2007).Ministério da Saúde. (2011). Vigitel Brasil 2011. Vigilância de fatores de risco e proteção para as doenças crônicas para inquérito telefonico. Dados sobre diabetes.: Ministério da Saúde recuperado em 10 de outubro de 2014 http://

portalsaude.saude.gov.br/portalsaude/arquivos/pdf/2012/Mai/09/Vigitel_2011_diabete s_final.pdf.

Sebastiane, R. W. (1997). Mecanismos de defesa do ego. A eleição do orgão de choque Obstetrícia psicossomática (pp. 323). São Paulo: Atheneu.

Sifneos, P. E. (1989). Psicoterapia dinâmica breve : avaliação e técnica (pp. 275). Porto Alegre: Artes Médicas.

Simon, R. (1989). Psicologia clínica preventiva. Novos fundamentos. . São Paulo: EPU.

Simon, R. (1997). Proposta de redefinição da E.D.A.O. Escala Diagnóstica Adaptativa Operacionalizada. Boletim de Psicologia, 47(107), 85-93.

Simon, R. (2005). Psicoterapia breve operacionalizada. Teoria e técnica. São Paulo: Casa do psicólogo

Simon, R. (2008). Psicoterapia breve operacionalizada em situação de crise adaptativa. Psicoterapia breve operacionalizada em situação de crise adaptativa.

Simon, R. (2010). Psicoterapia Psicanalítica. Concepção original. Teoria, técnica,pesquisa, ilustrações clínicas. São Paulo: Casa do Psicólogo.

Simon, R. (2011). "ferramentas" para prognóstico e prevenção nas crises adaptativas. São Paulo: IV Simósio de Psicoterapia Breve Operacionalizada, UNIP paraíso. 
Simon, R. (2014). ampliações da notação do diagnóstico adaptativo (EDAO) e repercurssões preventivas no prognóstico.

Simon, R., \& Yamamoto, K. (2009). Psicoterapia breve operacionalizada na clínica privada. Aletheia, 172-182.

Steiner, J. (1997). Refúgios Psíquicos. Organizações patológicas em pacientes psicóticos, neuróticos e fronteiriços. Rio de Janeiro: Imago.

Szejer, M., \& Stewart, R. (1997). Nove meses na vida da mulher. Uma abordagem psicanalítica da gravidez e do nascimento. São paulo: Casa do psicólogo.

Tamagnini, E. J. G. (2009). Transplante cardíaco: Sistema tensional inconsciente dominante e diagnóstico adaptativo operacionalizada de mulheres candidatas a enxerto. Dissertação de Mestrado, Universidade de São Paulo, São Paulo.

Tedesco, J. J. (1997). Aspectos emocionais da gravidez de alto risco Obstetrícia psicossomática (pp. 323). São Paulo: Atheneu.

Turato, E. R. (2000). Introdução à metodologia Clínico-Qualitativa. Definição e principais características. Revista Portuguesa de Psicossomática, 2(1), 93-108.

Turato, E. R. (2005). Métodos qualitativos e quantitativos na área da saúde: definições, diferenças e seus objetos de pesquisa Qualitative and quantitative methods in health: definitions, differences and research subjects. Revista de Saúde Pública, 39(3), 507.

Valentim, N. d. S. (2010). Delineamento do perfil adaptativo/psicológico de mães de crianças abrigadas. (Mestrado), Universidade de São Paulo, São Paulo.

Valle. (2008). Gestantes diabéticas compreensão clínica e consultas terapêuticas. São Paulo.

Winnicott, W. D. (1960). Teoria do relacionamento paterno-infantil O ambiente e os processos de maturação: Estudos sobre a teoria do desenvolvimento emocional. Porto Alegre: Artes Medicas.

Winnicott, W. D. (1988). Os bebês e suas mães. São Paulo: Martins Fontes.

Wutke, E. F. (2009). Estudo do psiquismo de gestantes com diabetes mellitus através do questionário para estilo de defes (DSQ) e questionário de morbidade psiquiátrica 
para adultos (QMPA). (Mestrado), Universidade Federal de Uberlandia, Uberlândia. Recuperado em 10 de outubro de 2014 http:// hdl.handle.net/123456789/2651

Yamamoto, K. (2004). Estudo da Eficácia Adaptativa de Trabalhadoras Noturnas Sugerindo Psicoterapia Breve Operacionalizada na Empresa. Mudanças, 12(1), 115-140.

Yamamoto, K., \& Simon, R. (2006). Eficácia da adaptação de pessoas com hipertensão essencial e uma avaliação com o Teste Estilocrômico. Mudanças, 14(2), 171-185.

Yin, R. K. (2001). Estudo de caso: planejamento e métodos (Vol. 2). Porto Alegre: Bookman.

Younes, A. J. (2011). Psicoterapia Breve Operacionalizada na crise adaptativa por perda: Um estudo exploratório. Dissertação de Mestrado, Universidade de São Paulo, São Paulo.

Younes, J. A., Lessa, F., Yamamoto, K., Coniaric, J., \& Ditzz, M. (2010). Psicoterapia Breve Operacionalizada e crise por expectativa de perda: Um estudo de caso. . Psicologia Argumento, 28(63), 303-311.Recuperado em 17 de junho de 2014 $<$ http://www2.pucpr.br/reol/index.php/PA?dd99=view\&dd98=\&dd1=3920\&idioma=2

Zagoneli, I. P. S., Martins, M., Pereira, K. F., \& Athayde, J. (2003).

O cuidado humano diante da transição ao papel materno: vivências no puerpério. Revista Eletrônica de Enfermagem, 5(2), 24 - 32.Recuperado em 30 de agosto de 2014 http:/www.fen.ufg.br/revista 
ANEXO A - Tabela da pontuação dos setores adaptativos e EDAO

Tabela 1 - Pontuação dos setores adaptativos AR (Afetivo Relacional) e Pr (produtividade)

\begin{tabular}{|c|c|c|c|}
\hline Setor & Adequado & Pouco adequado & Pouquíssimo adequado \\
\hline AR & 3 & 2 & 1 \\
\hline $\operatorname{Pr}$ & 2 & 1 & 0,5 \\
\hline
\end{tabular}

Tabela 2 - Escala Diagnóstica Adaptativa Operacionalizada

\begin{tabular}{|c|c|c|c|}
\hline Grupo & $\begin{array}{l}\text { Classificação } \\
\text { Diagnóstica }\end{array}$ & Soma & Pontuação \\
\hline 1 & $\begin{array}{l}\text { Adaptação } \\
\text { Eficaz }\end{array}$ & AR adequado + Pr adequado $=3+2$ & 5 \\
\hline 2 & $\begin{array}{c}\text { Adaptação } \\
\text { Ineficaz leve }\end{array}$ & $\begin{array}{l}\text { AR pouco adequado }+ \text { Pr adequado }=2+2 \\
\text { ou } \\
\text { AR adequado }+ \text { Pr pouco adequado }=3+1\end{array}$ & 4 \\
\hline 3 & $\begin{array}{l}\text { Adaptação } \\
\text { Ineficaz } \\
\text { moderada }\end{array}$ & $\begin{array}{c}\text { AR pouco adequado }+ \text { Pr pouco adequado }=2+1 \\
\text { ou } \\
\text { AR adequado }+ \text { Pr pouquíssimo adequado }=3+0,5 \\
\text { ou }\end{array}$ & $\begin{array}{c}3 \\
\text { ou } \\
3,5\end{array}$ \\
\hline
\end{tabular}




\begin{tabular}{|c|c|c|c|}
\hline & & AR pouquíssimo adequado + Pr adequado $=1+2$ & \\
\hline \multirow{2}{*}{4} & Adaptação & AR pouquíssimo adeq. + Pr pouco adeq. $=1+1$ & 2 \\
& Ineficaz & ou & ou \\
& severa & AR pouco adeq. + Pr pouquíssimo adeq. $=2+0,5$ & 2,5 \\
\hline \multirow{2}{*}{5} & Adaptação & AR pouquíssimo adeq. + Pr pouquíssimo adeq. & \\
& Ineficaz Grave & $1+0,5$ & 1,5 \\
\hline
\end{tabular}

ANEXO B - Folha para controle dos dextros e aplicações de insulina 


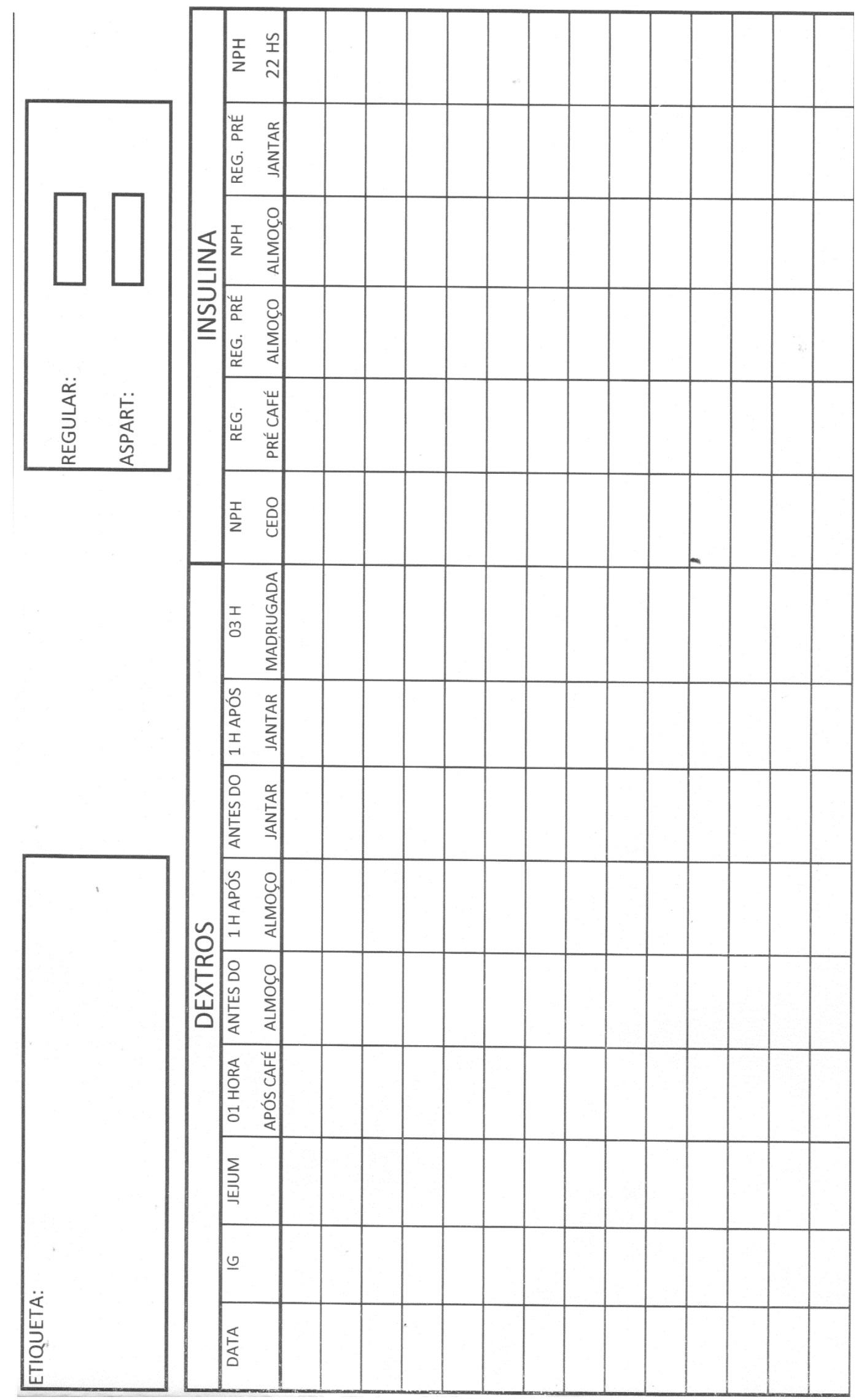

ANEXO C - Termo de Consentimento Livre e Esclarecido 
HOSPITAL DAS CLÍNICAS DA FACULDADE DE MEDICINA DA UNIVERSIDADE DE SÃO PAULO-HCFMUSP

TERMO DE CONSENTIMENTO LIVRE E ESCLARECIDO

DADOS DE IDENTIFICAÇÃO DO SUJEITO DA PESQUISA OU RESPONSÁVEL LEGAL

1. NOME:

DOCUMENTO DE IDENTIDADE $\mathrm{N}^{\circ}$ : SEXO: $M \square F \square$

DATA NASCIMENTO:

ENDEREÇO $\mathrm{N}^{\mathrm{o}}$ APTO:

BAIRRO: ..CIDADE

CEP: TELEFONE:( )

\section{DADOS SOBRE A PESQUISA}

2. TÍTULO DO PROTOCOLO DE PESQUISA: Psicoterapia Breve Operacionalizada - Possibilidades e limites em gestantes com Diabetes Mellitus 1.

PESQUISADOR: Lívia Maria Ramos Batista.

CARGO/FUNÇÃO: Psicóloga

INSCRIÇÃO CONSELHO REGIONAL No 06-77764.

UNIDADE DO HCFMUSP: Clínica de Obstetrícia.

3. AVALIAÇÃO DO RISCO DA PESQUISA:

$\begin{array}{llr}\text { RISCO MÍNIMO } & \text { x } & \text { RISCO MÉDIO } \\ \text { RISCO BAIXO } \square & & \text { RISCO MAIOR }\end{array}$

4.DURAÇÃO DA PESQUISA: 30 meses. 
As informações aqui apresentadas buscam esclarecer sobre sua participação voluntária neste estudo, que tem por objetivo ver se a Psicoterapia Breve Operacionalizada pode ajudar gestantes com diabetes mellitus tipo 1. Quero entender se é possível melhorar o controle glicêmico e se ocorrem mudanças na sua adaptação após a psicoterapia e se caso você estiver passando por um momento de crise, ver se consegue lidar com a crise sem diminuir sua adaptação, além de investigar as possibilidades e limites da psicoterapia breve operacionalizada quando realizada dentro do hospital.

Faremos de 2 a 6 entrevistas inicias para o diagnóstico adaptativo operacionalizado e planejamento da Psicoterapia Breve Operacionalizada. Após o diagnóstico será definido o número de sessões de psicoterapia (no máximo 12 sessões) e haverá um acordo verbal entre nós, contendo o número de sessões que serão realizadas. Os atendimentos terão duração de 45 minutos e frequência de 1 vez por semana. As entrevistas e o processo psicoterápico ocorrerão dentro da Clínica de Obstetrícia do HCFMUSP, de preferência nos mesmos dias em que você já estiver presente para consultas ou procedimentos. Caso ocorra durante a pesquisa sua internação, o atendimento será realizado na enfermaria da Clínica de Obstetrícia do HCFMUSP. Após a finalização da Psicoterapia Breve Operacionalizada será reavaliado seu diagnóstico adaptativo.

Estes dados coletados poderão ser solicitados a qualquer momento por você. Você poderá entrar em contato conosco sempre que quiser. Caso você se arrependa depois de ter assinado este termo de consentimento, é só nos comunicar que você será retirada da pesquisa. O seu nome será mantido em segredo. Caso tenha alguma dúvida, pode nos procurar, pois estaremos prontos para atendê-la. Lembramos que esses dados serão utilizados para pesquisa sem mencionar o seu nome e dados que possam identifica-la.

Este estudo oferece baixo risco a gestante. Você pode sentir algum desconforto emocional por estar falando sobre seus sentimentos e questões íntimas, mas, não é esperado que a Psicoterapia Breve Operacionalizada cause qualquer prejuízo físico ou emocional. Pelo contrário, esperamos que a psicoterapia traga benefícios, melhorando sua adaptação e seu controle glicêmico. Sempre será levado em consideração seu estado especial devido a gravidez, e assim, o atendimento será realizado com cautela para evitar qualquer condição adversa. Será conversado com você sobre os resultados da avaliação e esta será anexada ao seu prontuário. Ao término ou interrupção da Psicoterapia Breve Operacionalizada, você poderá, caso tenha interesse em continuar a ser atendida, ser encaminhada para a Clínica Psicológica Durval Marcondes do Instituto de Psicologia da USP.

Em qualquer etapa do estudo os profissionais responsáveis pela pesquisa estarão disponíveis para esclarecimento de eventuais dúvidas. O principal investigador é a psicóloga Lívia Maria Ramos Batista, que pode ser contatada no celular (11) 99393 1847, telefone: (11) 38816794 ou E-mail: liviamaria@usp.br. Você também pode entrar em contato com Orientadora Prof.a ${ }^{a}$ Dr $^{\mathrm{a}}$ Kayoko Yamamoto - Endereço: Av. Professor Mello Morais, 1721, Bloco F, Cidade Universitária, São Paulo Telefones: (11) 30914173 e 30911947.

Você levará para casa uma via do Termo de Consentimento Livre e Esclarecido para possível consulta posterior. Em caso de alguma consideração ou dúvida sobre a ética da pesquisa, entre em contato com o Comitê de Ética em Pesquisa (CEP) - Rua Ovídio Pires de Campos, 225 - $5^{\circ}$ andar tel.: 2661-6442 ramais 16, 17, 18 - e-mail: cappesq@hcnet.usp.br. Ou ainda no Comitê de Ética em 
Pesquisa com Seres Humanos - IPUSP - Av. Professor Mello Moraes, 1721 - Bloco G, $2^{\circ}$ andar, sala 27 - CEP 05508-030 - Cidade Universitária - São Paulo/SP - E-mail: ceph.ip@usp.br - Telefone: (11) 3091-4182

É garantida a liberdade da retirada de consentimento a qualquer momento e deixar de participar do estudo, sem qualquer prejuízo à continuidade de seu tratamento na Instituição. Todas as informações coletadas serão mantidas em sigilo e os únicos que terão acesso serão os pesquisadores responsáveis pelo estudo, não sendo divulgada a identificação de nenhum paciente.

Não há despesas pessoais para o participante em qualquer fase do estudo pois a paciente já se encontrará no local do atendimento devido ao acompanhamento médico pré-natal. Também não há compensação financeira relacionada à sua participação. É garantida indenização diante de eventuais danos decorrentes da pesquisa diante de determinação judicial. O pesquisador se compromete a utilizar os dados e o material coletado somente para esta pesquisa.

\section{HOSPITAL DAS CLÍNICAS DA FACULDADE DE MEDICINA DA UNIVERSIDADE DE SÃO PAULO-HCFMUSP}

Acredito ter sido suficientemente informada a respeito das informações que li ou que foram lidas para mim, descrevendo o estudo: ” Psicoterapia Breve Operacionalizada - Possibilidades e limites em gestantes com Diabetes Mellitus 1".

Eu discuti com a pesquisadora Lívia Maria Ramos Batista sobre a minha decisão em participar nesse estudo. Ficaram claros para mim quais são os propósitos do estudo, os procedimentos a serem realizados, desconfortos e riscos, as garantias de confidencialidade e de esclarecimentos permanentes. Ficou claro também que minha participação é isenta de despesas e que tenho garantia do acesso a tratamento hospitalar quando necessário. Concordo voluntariamente em participar deste estudo e poderei retirar o meu consentimento a qualquer momento, antes ou durante o mesmo, sem penalidades ou prejuízo ou perda de qualquer benefício que eu possa ter adquirido, ou no meu atendimento neste Serviço.

Assinatura do paciente/representante legal Data $\frac{1}{1}$

Assinatura da testemunha

Data 11

Para casos de pacientes menores de 18 anos, analfabetos, semianalfabetos ou portadores de deficiência auditiva ou visual.

\section{(Somente para o responsável do projeto)}

Declaro que obtive de forma apropriada e voluntária o Consentimento Livre e Esclarecido deste paciente ou representante legal para a participação neste estudo.

Data

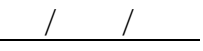

